\title{
Geochemical and mineralogical characteristics of fault gouge in the Median Tectonic Line, Japan: evidence for earthquake slip
}

\author{
Tsuyoshi Ishikawa ${ }^{1 *}$, Tetsuro Hirono ${ }^{2}$, Noriko Matsuta ${ }^{2}$, Kazuro Kawamoto ${ }^{3}$, Koichiro Fujimoto $^{4}$, Jun Kameda, ${ }^{5,}$ \\ Yoshiro Nishio ${ }^{7}$, Yuka Maekawa ${ }^{2}$ and Go Honda²
}

\begin{abstract}
We carried out geochemical and mineralogical analyses on fault-zone rocks from the Anko section of the Median Tectonic Line in Nagano Prefecture, Japan, to investigate coseismic physicochemical processes in the fault zone. The latest fault zone in the Anko section contains cataclasite, fault breccia, and fault gouge of granitic composition, and brecciated basic schist. Protoliths of the granitic composition are from the Ryoke metamorphic belt and those of the basic schist from the Sambagawa metamorphic belt. X-ray diffraction analyses show a selective decrease of clay minerals coupled with an increase of amorphous phase in an intensely deformed layer of black gouge (5- to 10-cm thick). SEM observation reveals that the black gouge is characterized by a drastic reduction of grain size and abundant ultrafine particles of submicrometer to several tens of nanometers with well-rounded spheroidal shapes. These observations for the black gouge are indicative of strong mineral lattice distortion and granulation associated with earthquake slip. Geochemically, the black gouge is characterized by distinctly higher Li content and ${ }^{87} \mathrm{Sr} /{ }^{86} \mathrm{Sr}$ isotope ratio than surrounding cataclasites, breccias, and gouges, which have similar major element compositions. Model analysis reveals that the trace element composition of the black gouge is consistent with high-temperature (up to $250^{\circ} \mathrm{C}$ ) coseismic fluid-rock interactions. Thermal and kinetic constraints indicate that there have been repeated slips on the fault at moderate depths (e.g., $600 \mathrm{~m}$ ), although the tectonic process by which the fault zone has been uplifted and exposed in this area is not well understood.
\end{abstract}

Keywords: Active fault; Frictional heat; Fault gouge; Trace elements; Isotope ratios

\section{Background}

Transient frictional heating in a fault zone during earthquake slip affects the slip behavior itself. Increased temperature on a fault can induce dynamic fault weakening by processes such as pressurization of interstitial fluid by thermal expansion, known as thermal pressurization (Sibson 1973; Lachenbruch 1980; Andrews 2002), and melt lubrication (Sibson 1975; Fialko and Khazan 2005). Geochemical and mineralogical analyses of fault rocks combined with geological, structural, and geophysical observations can provide useful means for elucidating such slip-weakening processes. In the case of the Chelungpu fault in Taiwan, which slipped during the $1999 \mathrm{M}_{\mathrm{w}} 7.6$

\footnotetext{
* Correspondence: t-ishik@jamstec.go.jp

${ }^{1}$ Kochi Institute for Core Sample Research, Japan Agency for Marine-Earth Science and Technology (JAMSTEC), 200 Monobe-otsu, Nankoku Kochi 783-8502, Japan Full list of author information is available at the end of the article
}

Chi-Chi earthquake (Ma et al. 1999), the slip-zone rocks show marked anomalies in both fluid-mobile trace element concentrations $(\mathrm{Sr}, \mathrm{Cs}, \mathrm{Rb}$, and $\mathrm{Li}$ ) and $\mathrm{Sr}$ isotope ratios that are consistent with fluid-rock interactions at $>350^{\circ} \mathrm{C}$ (Ishikawa et al. 2008). Thermal signals recorded in the slip-zone minerals (Mishima et al. 2006; Hirono et al. 2007) and the low permeability of the fault zone (Doan et al. 2006; Tanikawa et al. 2009) strongly suggest that thermal pressurization took place during the earthquake (Ishikawa et al. 2008). Geochemical analyses of the slip-zone rocks accompanied with generation of pseudotachylite in an ancient megasplay fault in the Shimanto accretionary complex (Mukoyoshi et al. 2006) are also indicative of fluid-rock interactions at $>350^{\circ} \mathrm{C}$ (Honda et al. 2011). These observations provide a key for gaining a detailed understanding of slip processes in the presence of pore fluids. 
However, there have been few studies of coseismic geochemical and mineralogical processes in fault zones that have investigated both the geochemistry of hightemperature fluid-rock interactions and structural observations. Three of the previously studied faults are the Chelungpu fault (Ishikawa et al. 2008), the major thrust of the Boso accretionary complex, Japan (Hamada et al. 2011), and the ancient megasplay fault of the Shimanto accretionary complex, Japan (Honda et al. 2011). Lithology, stress, temperature conditions, maturation (repeated activity and slip accumulation) and tectonic history may influence which coseismic physicochemical processes occur in slip zones, and how they occur. The aforementioned three faults are within sedimentary rocks (mudstone and sandstone) and are considered to be branch faults from plate-subduction megathrusts or major thrusts within the accretionary prism near a megathrust (Ishikawa et al. 2008; Hamada et al. 2011; Honda et al. 2011).

In this study, we focused on a fault from the Anko section of the Median Tectonic Line (MTL) in Nagano Prefecture, Japan, an inland fault in rocks of different lithology from the previous studies. We examined the structural, geochemical, and mineralogical characteristics of the fault zone and surrounding rocks to assess the relationship of coseismic fluid-rock interactions and other physicochemical processes in the slip zone with earthquake slip.

\section{Methods}

\section{Geological background and outcrop of the MTL at the Anko section}

The MTL is a major crustal-scale fault that was first active in the Cretaceous. It has a strike length of $>1,000 \mathrm{~km}$ and shows displacements of 200 to $1,000 \mathrm{~km}$ (Ichikawa 1980). The MTL is the dominant geological structure in southern Nagano Prefecture, where it strikes approximately N-S with subvertical dip and a left-lateral displacement of $60 \mathrm{~km}$ (Figure 1b). Collision of the Izu-Bonin arc of the Philippine Sea plate with the Eurasia plate at 27 to $15 \mathrm{Ma}$ produced a counterclockwise rotation of the MTL to a NNE-SSW strike (Matsushima 1994).

The Anko section along the Aoki River (Figure 1b) exhibits the main boundary fault of the MTL strikes NNE-SSW with a subvertical dip, which separates the Ryoke and the Sambagawa belts (Figure 2; Kawamoto et al. 2013a). West of the boundary, the Ryoke belt rocks are cataclasites derived from granitic or gneissic mylonite and altered dark breccia. East of the boundary, the Sambagawa belt rocks are partly brecciated or cataclastic greenschist, pelitic schist, and serpentinite. However, the altered dark breccia of the Ryoke belt are displaced by a minor low-dip fault (Tanaka et al. 1996).

A previously unrecognized mesoscale fault, approximately $40 \mathrm{~m}$ west of and parallel to the main boundary
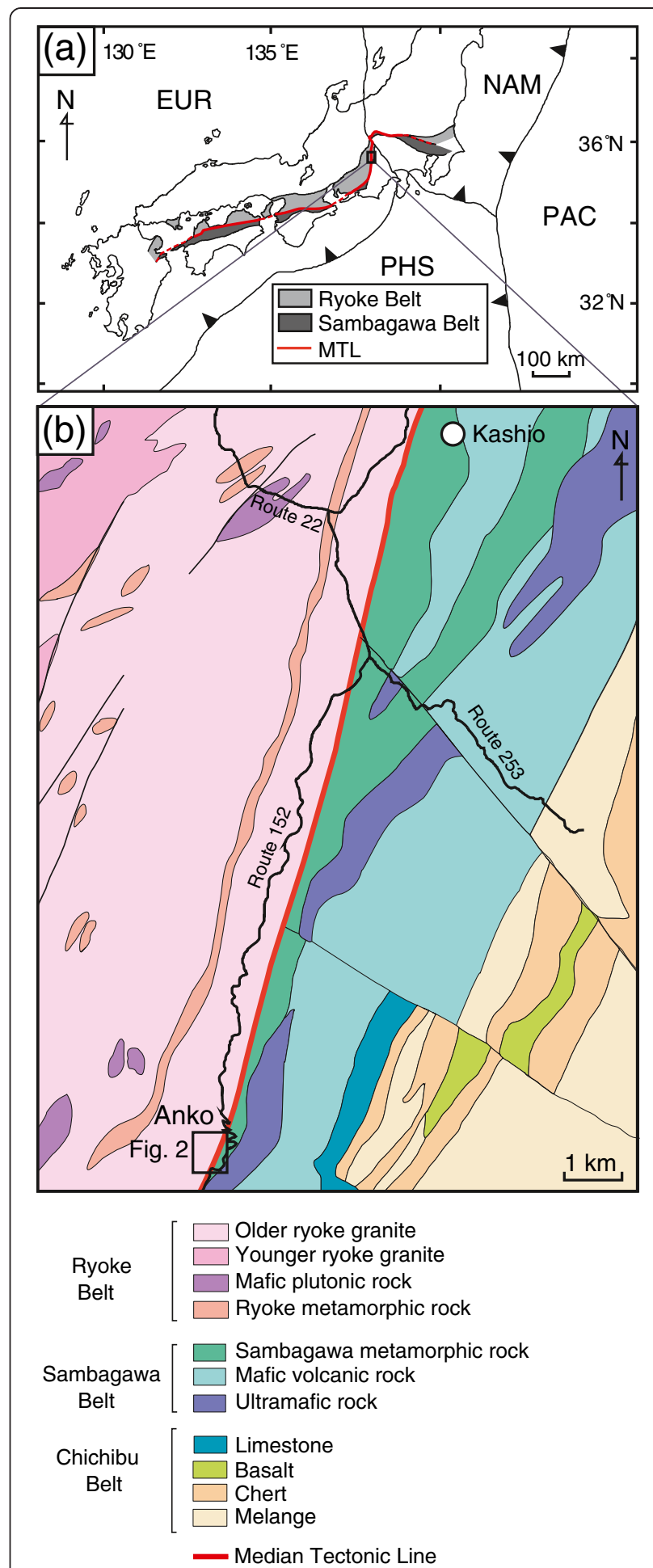

Figure 1 Index map (a) and simplified structural map (b) in the region of the MTL in southern Nagano Prefecture.

fault, was exposed by floodwaters in the summer of 2010 (Figure 2). Because this fault has not been displaced by any subsequent deformations (Figure 3), we consider the fault to be the latest fault zone in the Anko section of 


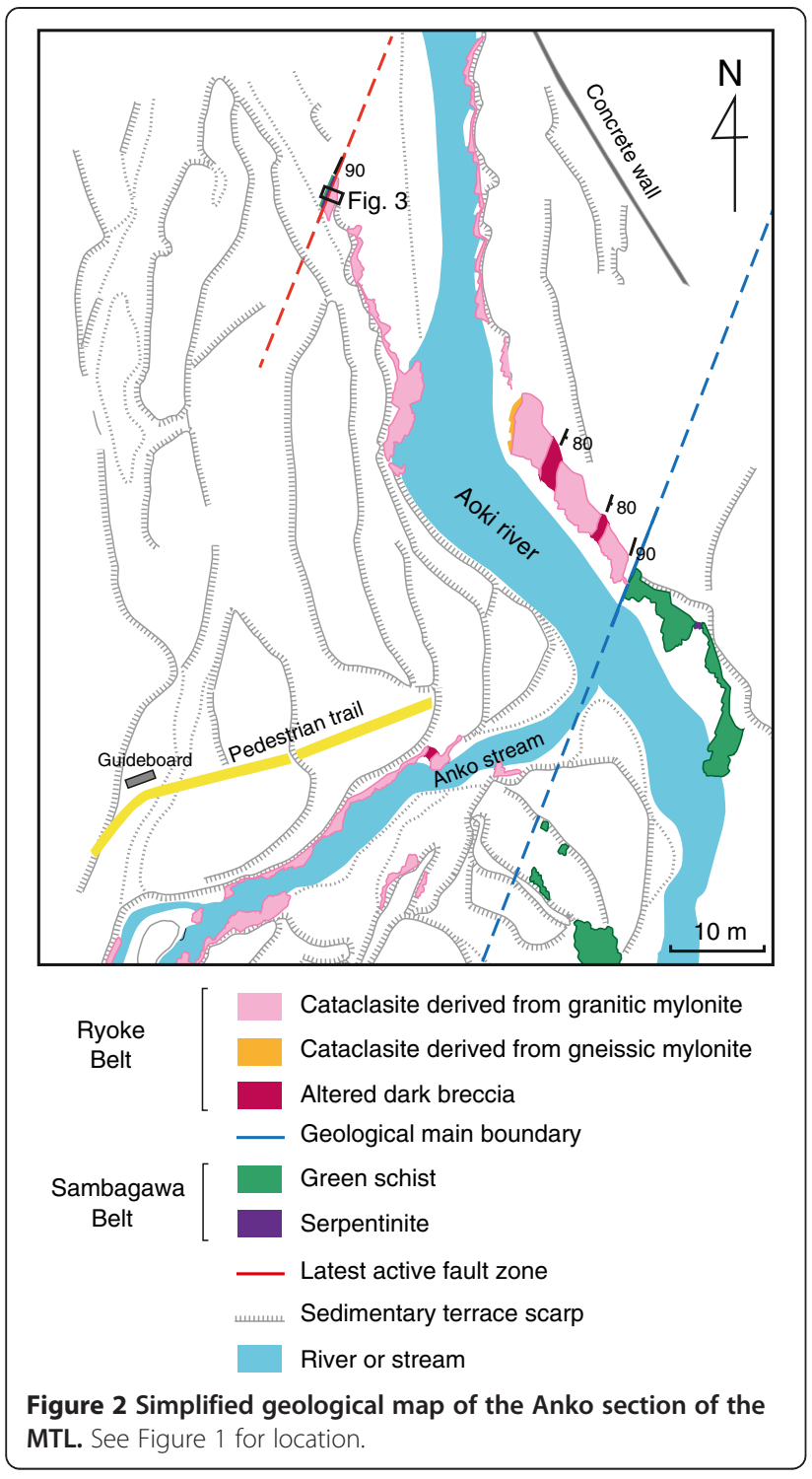

the MTL. This fault zone contains, from east to west, orange-stained cataclasite (up to 1-m thick), gray breccia with some gouge (20- to $30-\mathrm{cm}$ thick), black gouge (5- to $10-\mathrm{cm}$ thick), gray-green gouge (15- to $20-\mathrm{cm}$ thick), and brecciated greenschist extending to the west (Figure 3). The orange-stained cataclasite is partly brecciated with rounded clasts and is comminuted with weak foliation. The boundary between the cataclasite and the gray breccia is gradual, and the rounded clasts and elongated tails from the cataclasite are incorporated in the breccia, exhibiting a complex flow structure with isoclinal folds. The black gouge is highly foliated with a dense, closely spaced, dark network of seams. The gray-green gouge is foliated with composite planar fabrics accompanying the well-developed Riedel slip surface $\left(\mathrm{R}_{1}\right.$-plane) described above. The fabrics indicate dextral shear deformation. The elongated clasts aligned with the $R_{1}$-plane are derived from the adjacent gouge layers. The contact between the gray-green gouge and the brecciated greenschist is sharp and straight, corresponding to the Riedel shear Y-plane. There are serpentinite blocks within the brecciated greenschist.

\section{Sample collection}

For mineralogical and geochemical investigation, we collected 12 samples from the fault zone: two from the orange-stained cataclasite, three from the gray breccia, one from the black gouge, two from the gray-green gouge, and four from the brecciated greenschist (samples FZ01 to FZ12 in Figure 3). Additional three samples were collected from the black gouge zone (samples FZ06b to FZ06d; up to $2 \mathrm{~m}$ from FZ06 but beyond the extent of Figure 3) for trace element and isotope analyses. We also collected some oriented samples from the fault zone for microscopic observations.

\section{Microscopic observation}

To observe the microscopic structures and fabrics in the fault zone, we used polarization microscope and scanning electron microscope (SEM: JSM-6500 F, JEOL, Tokyo, Japan) operated at an acceleration voltage of $10 \mathrm{kV}$. Thin sections were prepared to be the plane perpendicular to the mesoscopic foliation and/or structural zone boundaries. The samples for the SEM observation were prepared by being dispersed in ethanol and then dropped on the observation stage.

\section{$\mathrm{X}$-ray diffraction analysis}

X-ray diffraction (XRD) with monochromatized $\mathrm{CuK \alpha}$ radiation (Spectris PANalytical, X'Pert PRO MPD, Almelo, the Netherlands) was used to analyze the mineralogy of the samples. Each sample was gently powdered in an agate mortar. Part of each original sample was mixed with $\alpha$-alumina (25 wt.\%) for use as an internal standard. These samples were then mounted on XRD glass holders, side-loaded to minimize preferred alignment of phyllosilicates. XRD patterns were obtained with the spectrometer operated at $45 \mathrm{kV}, 40 \mathrm{~mA}, 0.004^{\circ}(\Delta 2 \theta)$ step width with $0.25^{\circ}$ divergence, anti-scattering slits, and a high-speed semiconductor array detector. For quantitative determination of the mineral composition of the samples containing $\alpha$-alumina, we used the RockJock program of Eberl (2003). The XRD patterns were compared with integrated XRD patterns of standard minerals stored in the RockJock program, and the weight percent of the component minerals in the samples was determined.

The XRD patterns of some samples on a zero diffraction plate, made from a single silicon crystal, were obtained under the same operating conditions at around $20^{\circ}$ to $30^{\circ}$ 


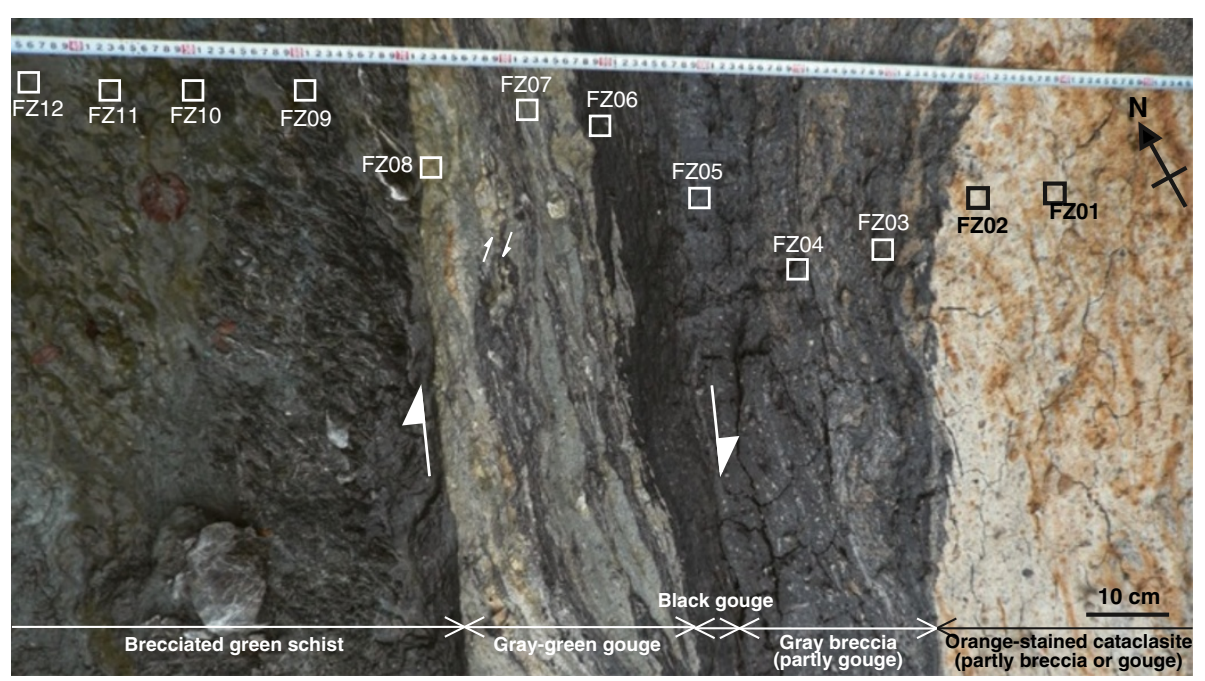

Figure 3 Photographs of the most recently active fault zone in the Anko section of the MTL. White arrows indicate dextral sense of slip Structural divisions of the fault-zone rocks and sampling points for mineralogical and geochemical analyses are also shown.

$2 \theta$ for evaluation of a broad bump caused by amorphous state.

The clay fraction $(<2 \mu \mathrm{m})$ was separated by centrifugation from each of the bulk-powdered samples (without $\alpha$-alumina). Oriented samples of the clay fraction were prepared by sedimentation onto glass slides in dry air. XRD patterns were obtained using the spectrometer operated under the same conditions as for the internal standard determinations. XRD analysis was also undertaken for the clay fraction saturated with ethylene glycol vapor. The relative abundances of kaolinite, smectite, illite, and chlorite were calculated by the method of Biscaye (1965).

\section{Major and trace elements and Sr isotope analyses}

Major element concentrations were measured with an Xray fluorescence spectrometer (XRF: MagiX PRO, Spectris) using the conventional glass bead method. Trace-element concentrations were measured with an inductively coupled plasma mass spectrometer (ICP-MS: ELAN DRC II, Perkin Elmer) after sample decomposition with $\mathrm{HF}-\mathrm{HNO}_{3} . \mathrm{Sr}$ isotope ratios were determined with a thermal ionization mass spectrometer (TIMS: TRITON, Thermo Finnigan, Bremen, Germany) after chemical separation of Sr using an ion-exchange resin column (Sr Resin, Eichrom, Lisle, IL, USA). Replicate analyses $(N=5)$ of the NIST SRM 987 $\mathrm{Sr}$ isotope standard during this study yielded a mean value $( \pm 2 \mathrm{SD})$ of ${ }^{87} \mathrm{Sr} /{ }^{86} \mathrm{Sr}=0.710251 \pm 0.000018$. The trace element concentrations and $\mathrm{Sr}$ isotope data obtained for reference rock material Geological Survey of Japan JB-3 (Table 1) were consistent with the reported values (Geochemical reference samples database of Geological Survey of Japan: http://riodb02.ibase.aist.go.jp/geostand/).

\section{Results}

Microscopic structures and fabrics

The microscopic structures and fabrics of oriented samples from the fault zone were examined in thin section.

The orange-stained cataclasite is composed of abundant recrystallized quartz grains $(<1 \mathrm{~mm})$, which are partly displaced and fragmented by minor faults and surrounded by carbonate veins and a matrix of clay minerals (Figure 4a). The gray breccia is composed of an abundant matrix of clay minerals and carbonate cements supporting fragments of recrystallized quartz grains (Figure $4 \mathrm{~b}$ ). No intense foliation is evident in either of these rocks.

In contrast, the black gouge exhibits highly intense foliation, indicated by the preferred orientation of grains (submicron to several tens of microns) of fragmented quartz, K-feldspar, plagioclase, carbonate minerals (veins), and clay minerals (Figure 4c,d). Anastomosing black seams, probably chlorite, are developed parallel to the foliation.

The gray-green gouge is composed of abundant fragmented grains of quartz, K-feldspar, and plagioclase accompanied by carbonate veins and a matrix of very fine-grained clay minerals (Figure 4e).

The brecciated greenschist shows mylonitic foliation, which is composed of amphibole porphyroclasts with tails and fish of clay minerals (Figure 4f). Very fine grains of serpentinite are locally observed in the brecciated greenschist.

SEM observation of the black gouge sample (Figure 5a, b) confirmed a drastic reduction of particle size compared with the surrounding gouge samples (Figure $5 \mathrm{c}, \mathrm{d}$ ). The particles in the black gouge sample ranged in size from submicrometer to several tens of nanometers and had well-rounded spheroidal shapes. However, such ultrafine particles were scarcely observed in the surrounding gouge samples. 
Table 1 Major and trace element concentrations and $\mathrm{Sr}$ isotope ratio of the fault gouges and surrounding rocks

\begin{tabular}{|c|c|c|c|c|c|c|c|c|c|c|c|c|c|c|c|c|}
\hline & FZ01 & FZ02 & FZ03 & FZ04 & FZ05 & FZ06 & FZ06b & FZ06c & FZ06d & FZ07 & FZ08 & FZ09 & FZ10 & FZ11 & FZ12 & JB3 \\
\hline $\mathrm{SiO}_{2}$ & 67.47 & 66.75 & 67.50 & 70.98 & 72.06 & 62.97 & & & & 64.23 & 63.31 & 42.09 & 44.57 & 46.57 & 45.89 & \\
\hline $\mathrm{TiO}_{2}$ & 0.81 & 0.90 & 0.72 & 0.61 & 0.60 & 0.79 & & & & 0.83 & 0.70 & 0.39 & 1.26 & 1.54 & 1.80 & \\
\hline $\mathrm{Al}_{2} \mathrm{O}_{3}$ & 18.30 & 17.96 & 16.42 & 16.78 & 15.97 & 14.50 & & & & 16.53 & 15.82 & 5.95 & 9.44 & 8.25 & 12.28 & \\
\hline $\mathrm{Fe}_{2} \mathrm{O}_{3}$ & 5.02 & 5.69 & 5.41 & 3.89 & 3.24 & 7.65 & & & & 6.60 & 5.08 & 13.35 & 14.84 & 13.86 & 14.89 & \\
\hline $\mathrm{MnO}$ & 0.09 & 0.10 & 0.12 & 0.09 & 0.06 & 0.13 & & & & 0.10 & 0.12 & 0.17 & 0.18 & 0.17 & 0.16 & \\
\hline $\mathrm{MgO}$ & 2.33 & 2.49 & 2.90 & 1.94 & 2.21 & 6.84 & & & & 3.18 & 2.67 & 33.98 & 22.21 & 20.80 & 15.26 & \\
\hline $\mathrm{CaO}$ & 3.20 & 2.93 & 3.78 & 1.98 & 2.12 & 4.13 & & & & 2.79 & 5.96 & 3.88 & 6.83 & 7.77 & 7.45 & \\
\hline $\mathrm{Na}_{2} \mathrm{O}$ & 0.08 & 0.07 & 0.07 & 0.10 & 0.13 & 1.08 & & & & 3.04 & 3.04 & 0.13 & 0.50 & 0.82 & 1.96 & \\
\hline $\mathrm{K}_{2} \mathrm{O}$ & 2.46 & 2.82 & 2.91 & 3.52 & 3.50 & 1.74 & & & & 2.50 & 3.11 & 0.03 & 0.07 & 0.10 & 0.14 & \\
\hline $\mathrm{P}_{2} \mathrm{O}_{5}$ & 0.23 & 0.29 & 0.15 & 0.10 & 0.10 & 0.18 & & & & 0.20 & 0.19 & 0.03 & 0.09 & 0.12 & 0.18 & \\
\hline $\mathrm{Li}$ & 48.1 & 43.0 & 37.2 & 29.9 & 26.2 & 66.7 & 67.7 & 62.7 & 65.6 & 44.9 & 32.4 & 16.8 & 16.1 & 10.5 & 14.1 & 7.10 \\
\hline $\mathrm{Be}$ & 0.958 & 1.15 & 1.19 & 1.09 & 1.33 & 1.52 & 1.41 & 1.52 & 1.84 & 1.34 & 0.926 & 0.179 & 0.230 & 0.409 & 0.344 & 0.612 \\
\hline $\mathrm{Ti}$ & 4,330 & 4,770 & 3,860 & 3,400 & 3,300 & 4,070 & 4,360 & 3,930 & 4,490 & 4,680 & 3,720 & 1,920 & 6,650 & 8,420 & 8,340 & 8,300 \\
\hline V & 97.7 & 111 & 89.0 & 75.8 & 82.9 & 107 & 109 & 102 & 117 & 120 & 100 & 92.1 & 275 & 282 & 319 & 406 \\
\hline $\mathrm{Cr}$ & 14.5 & 16.8 & 61.3 & 38.5 & 76.1 & 332 & 384 & 374 & 324 & 25.1 & 14.6 & 1,740 & 1,090 & 981 & 591 & 54.8 \\
\hline Co & 9.05 & 13.6 & 12.4 & 10.6 & 11.4 & 26.0 & 26.7 & 25.8 & 23.4 & 15.0 & 10.3 & 110 & 86.8 & 80.1 & 70.9 & 35.5 \\
\hline $\mathrm{Ni}$ & 17.4 & 11.1 & 23.7 & 18.8 & 45.7 & 2,045 & 198 & 236 & 212 & 15.1 & 14.4 & 1,550 & 960 & 951 & 526 & 41.3 \\
\hline $\mathrm{Cu}$ & 23.2 & 11.9 & 31.0 & 31.5 & 32.6 & 33.5 & 38.2 & 35.2 & 36.3 & 13.9 & 14.1 & 28.2 & 136 & 142 & 180 & 192 \\
\hline $\mathrm{Zn}$ & 84.5 & 84.6 & 77.3 & 58.3 & 61.1 & 78.0 & 91.4 & 81.0 & 87.1 & 91.1 & 68.3 & 58.7 & 88.6 & 89.9 & 91.6 & 112 \\
\hline $\mathrm{Rb}$ & 69.3 & 81.9 & 89.5 & 113 & 136 & 57.2 & 61.3 & 37.1 & 64.2 & 74.2 & 77.5 & 0.289 & 0.291 & 0.249 & 2.15 & 14.2 \\
\hline $\mathrm{Sr}$ & 242 & 209 & 281 & 231 & 206 & 155 & 155 & 174 & 171 & 302 & 357 & 57.4 & 73.9 & 90.6 & 1,390 & 412 \\
\hline$Y$ & 10.1 & 12.2 & 13.9 & 17.5 & 17.7 & 16.1 & 19.0 & 18.0 & 18.4 & 10.5 & 12.7 & 3.6 & 11.5 & 13.1 & 18.5 & 23.7 \\
\hline $\mathrm{Nb}$ & 7.94 & 9.34 & 12.3 & 14.4 & 13.4 & 10.1 & 10.2 & 9.43 & 10.4 & 9.64 & 8.11 & 0.63 & 2.30 & 3.27 & 6.94 & 1.95 \\
\hline Mo & 0.48 & 0.45 & 1.38 & 0.97 & 1.91 & 0.71 & 1.03 & 0.841 & 0.760 & 0.34 & 0.31 & 1.25 & 0.17 & 1.46 & 1.13 & 1.05 \\
\hline Cs & 19.3 & 23.8 & 23.3 & 30.7 & 72.6 & 18.8 & 22.1 & 12.4 & 18.2 & 14.9 & 15.2 & 0.367 & 0.329 & 0.191 & 0.443 & 0.945 \\
\hline $\mathrm{Ba}$ & 197 & 218 & 243 & 337 & 329 & 314 & 241 & 254 & 328 & 485 & 506 & 10.0 & 10.0 & 14.0 & 59.0 & 236 \\
\hline La & 32.6 & 35.1 & 28.8 & 33.7 & 31.8 & 21.8 & 23.4 & 23.1 & 20.9 & 15.8 & 21.4 & 1.20 & 2.70 & 4.40 & 7.30 & 8.22 \\
\hline $\mathrm{Ce}$ & 63.4 & 67.9 & 60.0 & 68.9 & 66.1 & 45.1 & 50.2 & 49.0 & 44.4 & 34.4 & 41.9 & 3.10 & 8.20 & 13.3 & 18.9 & 21.0 \\
\hline $\operatorname{Pr}$ & 7.00 & 7.20 & 6.58 & 7.41 & 7.22 & 4.98 & 5.68 & 5.51 & 5.12 & 3.96 & 4.67 & 0.454 & 1.34 & 2.15 & 2.75 & 3.15 \\
\hline $\mathrm{Nd}$ & 24.6 & 26.8 & 24.8 & 27.6 & 26.6 & 19.4 & 22.3 & 21.1 & 20.1 & 16.2 & 18.1 & 2.50 & 7.40 & 11.1 & 13.9 & 16.0 \\
\hline $\mathrm{Sm}$ & 4.25 & 4.79 & 4.80 & 5.15 & 5.00 & 3.84 & 4.47 & 4.16 & 4.21 & 3.17 & 3.61 & 0.680 & 2.38 & 3.10 & 3.80 & 4.13 \\
\hline $\mathrm{Eu}$ & 1.16 & 1.27 & 0.98 & 0.99 & 0.96 & 0.94 & 1.01 & 0.983 & 1.05 & 0.76 & 0.89 & 0.25 & 0.81 & 1.08 & 1.33 & 1.33 \\
\hline $\mathrm{Gd}$ & 3.31 & 3.79 & 3.85 & 4.26 & 4.06 & 3.36 & 4.15 & 3.94 & 3.83 & 2.73 & 3.04 & 0.835 & 2.68 & 3.28 & 4.24 & 4.70 \\
\hline
\end{tabular}


Table 1 Major and trace element concentrations and Sr isotope ratio of the fault gouges and surrounding rocks (Continued)

\begin{tabular}{|c|c|c|c|c|c|c|c|c|c|c|c|c|c|c|c|c|}
\hline $\mathrm{Tb}$ & 0.435 & 0.512 & 0.565 & 0.588 & 0.590 & 0.485 & 0.593 & 0.551 & 0.549 & 0.382 & 0.437 & 0.126 & 0.411 & 0.504 & 0.660 & 0.730 \\
\hline Dy & 2.22 & 2.64 & 2.86 & 3.29 & 3.43 & 3.11 & 3.51 & 3.37 & 3.21 & 2.18 & 2.48 & 0.797 & 2.61 & 2.89 & 4.02 & 4.72 \\
\hline Ho & 0.378 & 0.443 & 0.529 & 0.637 & 0.657 & 0.581 & 0.696 & 0.669 & 0.651 & 0.426 & 0.431 & 0.142 & 0.472 & 0.559 & 0.772 & 0.900 \\
\hline Er & 0.99 & 1.17 & 1.59 & 1.79 & 1.82 & 1.68 & 1.99 & 1.83 & 1.87 & 1.21 & 1.26 & 0.379 & 1.27 & 1.39 & 2.05 & 2.72 \\
\hline $\mathrm{Tm}$ & 0.127 & 0.156 & 0.215 & 0.252 & 0.295 & 0.242 & 0.279 & 0.272 & 0.258 & 0.163 & 0.169 & 0.045 & 0.150 & 0.176 & 0.289 & 0.390 \\
\hline $\mathrm{Yb}$ & 0.79 & 0.90 & 1.32 & 1.67 & 1.58 & 1.57 & 1.83 & 1.80 & 1.70 & 1.00 & 1.10 & 0.25 & 0.94 & 1.11 & 1.64 & 2.57 \\
\hline Lu & 0.112 & 0.123 & 0.186 & 0.234 & 0.239 & 0.221 & 0.264 & 0.239 & 0.241 & 0.143 & 0.148 & 0.034 & 0.125 & 0.151 & 0.234 & 0.390 \\
\hline Ta & 0.418 & 0.511 & 0.760 & 0.860 & 0.825 & 0.622 & 0.663 & 0.617 & 0.647 & 0.536 & 0.419 & 0.045 & 0.155 & 0.229 & 0.453 & 0.130 \\
\hline W & 1.49 & 1.89 & 2.97 & 1.94 & 2.23 & 2.53 & 2.30 & 2.13 & 2.38 & 1.25 & 0.674 & 1.24 & 0.340 & 0.511 & 0.263 & 1.09 \\
\hline $\mathrm{Tl}$ & 0.290 & 0.395 & 0.417 & 0.460 & 0.575 & 0.341 & 0.320 & 0.246 & 0.311 & 0.363 & 0.361 & 0.055 & 0.057 & 0.026 & 0.061 & 0.040 \\
\hline $\mathrm{Pb}$ & 8.62 & 13.0 & 8.19 & 14.7 & 10.6 & 10.8 & 10.9 & 11.2 & 10.6 & 10.5 & 11.7 & 0.288 & 0.242 & 0.231 & 1.67 & 5.00 \\
\hline Th & 6.44 & 7.43 & 11.8 & 16.3 & 15.8 & 6.46 & 7.29 & 6.88 & 6.55 & 4.05 & 4.55 & 0.049 & 0.155 & 0.251 & 0.680 & 1.34 \\
\hline U & 0.667 & 0.655 & 1.56 & 1.88 & 1.84 & 1.11 & 1.28 & 1.26 & 1.08 & 0.819 & 0.442 & 0.014 & 0.029 & 0.039 & 0.207 & 0.483 \\
\hline${ }^{87} \mathrm{Sr} /{ }^{86} \mathrm{Sr}$ & 0.707745 & 0.707876 & 0.707969 & 0.708416 & 0.708313 & 0.707812 & 0.708081 & 0.708114 & 0.707921 & 0.707038 & 0.707269 & 0.706611 & 0.704624 & 0.703684 & 0.703177 & 0.703420 \\
\hline
\end{tabular}

The units for major elements and trace elements are weight percent and ppm, respectively. 

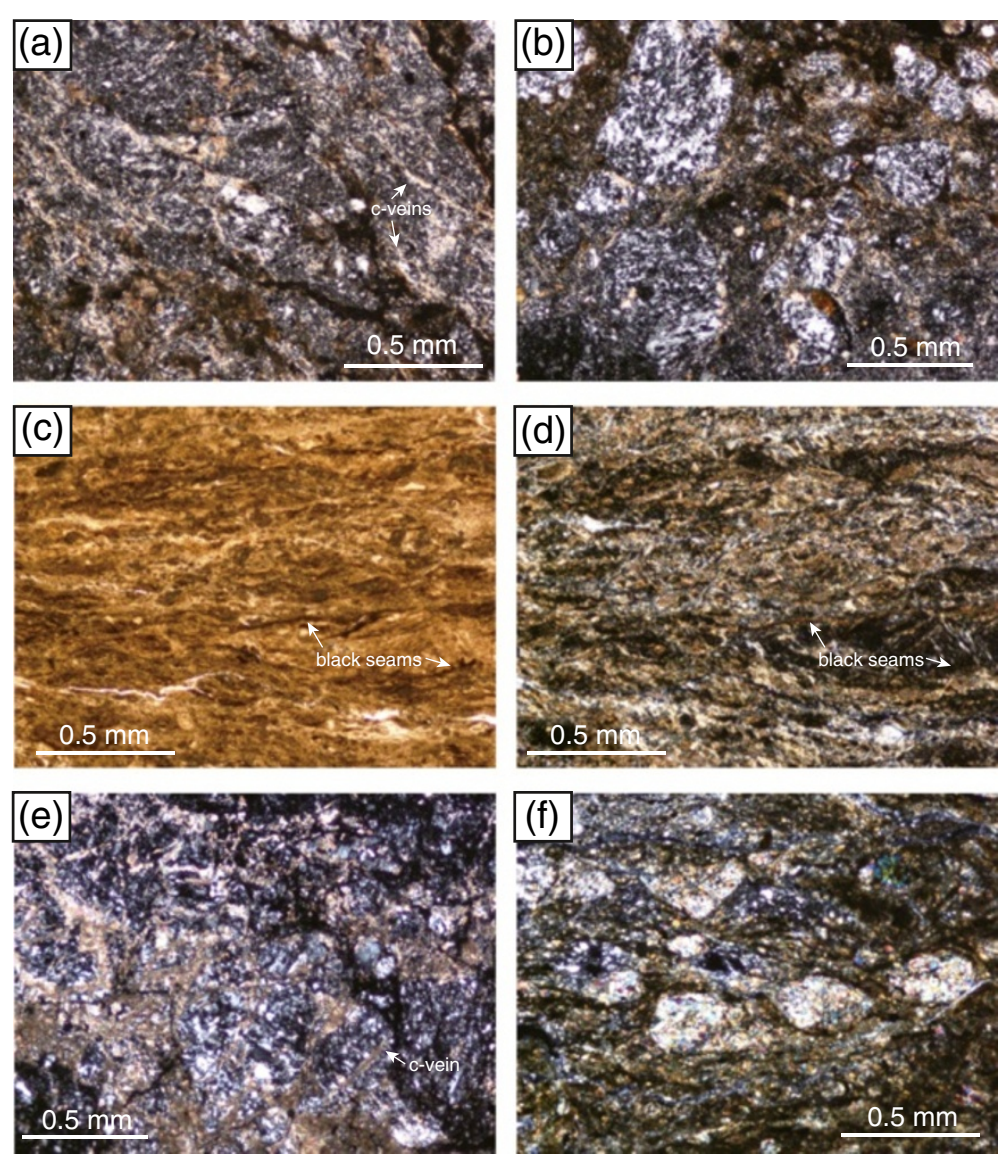

Figure 4 Microstructures in fault-zone rocks of most recently active fault zone in the Anko section of the MTL. (a) Orange-stained cataclasite, (b) gray breccia, (c) black gouge, (d) black gouge under cross-polarized light, (e) gray-green gouge, and (f) brecciated greenschist. c-vein, calcite vein.
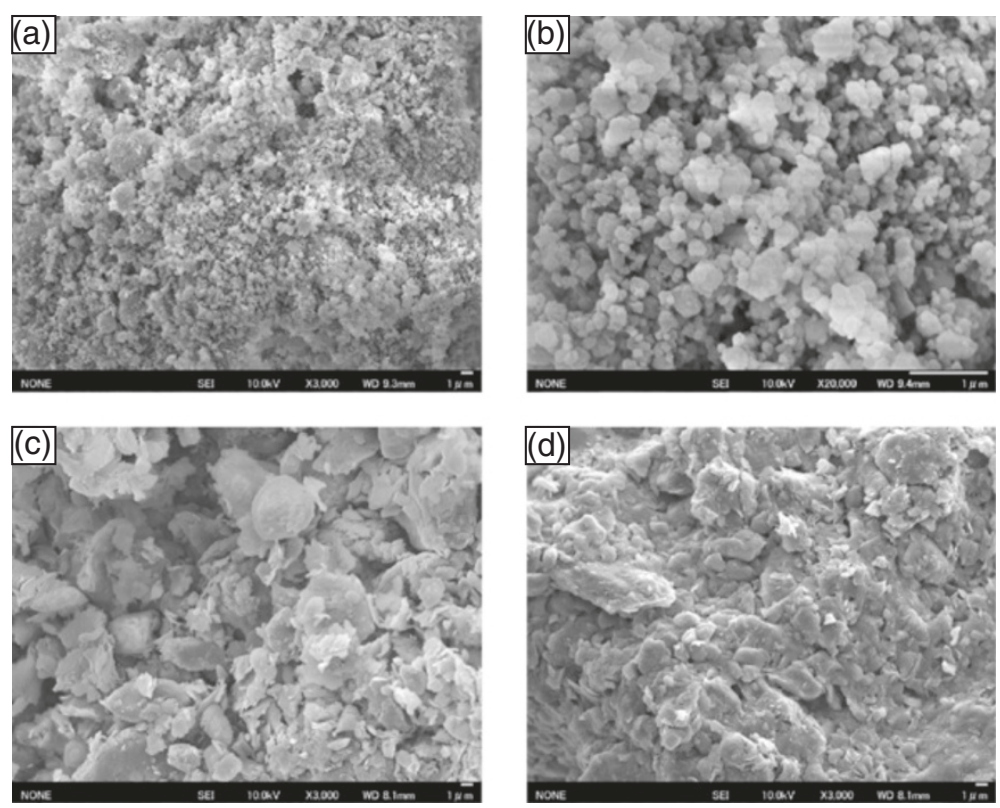

Figure 5 Fine structure by SEM observation. (a, b) black gouge (FZO6), (c) gray breccia (FZO5), and (d) gray-green gouge (FZ07). 


\section{Mineralogical characteristics}

XRD patterns of the bulk samples with internal standard $(\alpha$-alumina $)$ and clay fractions are shown in Figure 6, and bulk mineral compositions and clay mineral compositions, determined by the RockJock program and Biscaye analyses, respectively, are summarized in Table 2. Total percentages of minerals composited were approximately $83 \%$ to $109 \%$ except for sample FZ06 (71.8\%).

The orange-stained cataclasite (FZ01 and FZ02) consists mainly of quartz, illite, and kaolinite, with small amounts of carbonate minerals (siderite and ankerite). Clay minerals are predominantly illite. The gray breccia (FZ03 to FZ05) also consists of mainly of quartz, illite, and kaolinite with small amounts of siderite and ankerite. Illite is the dominant clay mineral.

The black gouge (FZ06) consists of quartz, plagioclase, K-feldspar, chlorite, illite, and ankerite. XRD intensities for the clay fraction are relatively weak. The total mineral abundances (71.8\%) estimated by the RockJock program are markedly lower in the black gouge than in the neighboring fault zone material.
The green-gray gouge (FZ07 and FZ08) also consists of quartz, plagioclase, chlorite, and illite with small amounts of ankerite and siderite. K-feldspar, kaolinite, and smectite were detected in only sample FZ08.

The brecciated greenschist (FZ09 to FZ12) consists mainly of amphibole and chlorite. Antigorite and lizardite were identified only in clasts incorporated in the schist (FZ09). Clay minerals in samples FZ09 to FZ12 are rich in chlorite.

The XRD patterns obtained by using the zero diffraction plate confirmed the presence of broad low bumps at around $20^{\circ}$ to $30^{\circ} 2 \theta$ in the black gouge sample but not in the surrounding gouge and breccia samples (Figure 7).

\section{Geochemical characteristics and identification of protoliths}

Major and trace element compositions and $\mathrm{Sr}$ isotope data obtained in this study are summarized in Table 1. Samples FZ01 to FZ08 (orange-stained cataclasite, gray breccia, black gouge, and gray-green gouge) show relatively high $\mathrm{SiO}_{2}$ and $\mathrm{Al}_{2} \mathrm{O}_{3}$ concentrations (about 63 to 71 and 15 to 18 wt.\%, respectively), whereas samples FZ09 to FZ12
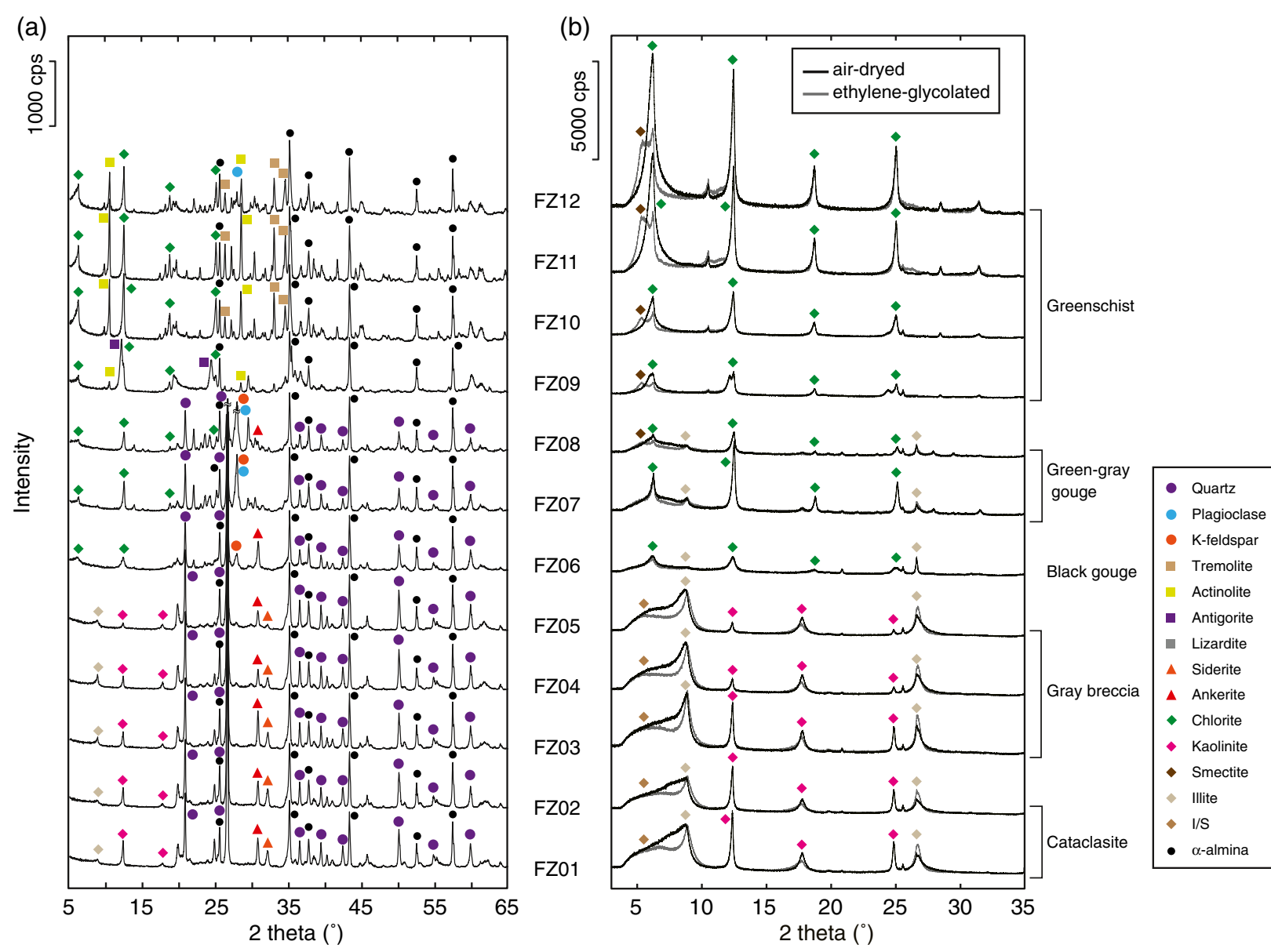

Figure 6 XRD patterns of (a) bulk samples and (b) clay fractions of samples FZ01 to FZ12. 
Table 2 Mineral compositions from X-ray diffraction data

\begin{tabular}{|c|c|c|c|c|c|c|c|c|c|c|c|c|}
\hline & FZ01 & FZ02 & FZ03 & FZ04 & FZ05 & FZ06 & FZ07 & FZ08 & FZ09 & FZ10 & FZ11 & FZ12 \\
\hline \multicolumn{13}{|c|}{ RockJock's bulk mineral composition } \\
\hline Quartz & 35.2 & 37.1 & 34.1 & 41.5 & 44.5 & 29.1 & 24.1 & 24.0 & 0.0 & 0.0 & 0.0 & 0.0 \\
\hline K-feldspar & 0.0 & 0.0 & 0.0 & 0.0 & 0.0 & 5.0 & 0.0 & 15.4 & 0.0 & 0.3 & 0.0 & 1.2 \\
\hline Plagioclase & 0.0 & 0.0 & 0.0 & 0.0 & 0.0 & 7.1 & 29.5 & 24.5 & 0.0 & 0.1 & 0.0 & 10.9 \\
\hline Dolomite & 0.3 & 0.4 & 0.6 & 1.3 & 1.2 & 2.5 & 0.0 & 0.0 & 0.0 & 0.1 & 0.0 & 0.0 \\
\hline Ankerite & 6.9 & 6.2 & 8.6 & 3.8 & 3.8 & 6.0 & 0.8 & 1.8 & 0.0 & 0.2 & 0.0 & 2.0 \\
\hline Siderite & 3.3 & 4.1 & 3.8 & 2.9 & 1.2 & 0.0 & 0.4 & 0.1 & 0.0 & 0.0 & 0.0 & 0.0 \\
\hline Amphibole & 0.0 & 0.0 & 0.0 & 0.0 & 0.0 & 0.0 & 0.0 & 0.0 & 3.0 & 31.8 & 50.9 & 28.9 \\
\hline Magnetite & 0.0 & 0.0 & 0.0 & 0.0 & 0.0 & 0.0 & 0.0 & 0.0 & 4.3 & 1.0 & 0.0 & 1.4 \\
\hline Forsterite & 0.0 & 0.0 & 0.0 & 0.0 & 0.0 & 0.0 & 0.0 & 0.0 & 3.6 & 0.6 & 0.0 & 0.0 \\
\hline Total non-clay & 45.7 & 47.8 & 47.1 & 49.5 & 50.7 & 49.7 & 54.8 & 65.8 & 10.9 & 34.1 & 50.9 & 44.4 \\
\hline Serpentine & 0.0 & 0.0 & 0.0 & 0.0 & 0.0 & 0.0 & 0.0 & 0.0 & 5.5 & 0.0 & 0.0 & 0.0 \\
\hline Kaolinite & 19.0 & 15.4 & 11.2 & 6.0 & 2.4 & 0.0 & 0.0 & 1.8 & 0.0 & 0.0 & 0.0 & 0.0 \\
\hline Smectite & 0.0 & 0.0 & 0.0 & 0.0 & 0.0 & 0.0 & 0.0 & 6.7 & 30.4 & 13.1 & 10.1 & 12.9 \\
\hline Illite & 22.9 & 26.0 & 24.8 & 32.2 & 39.3 & 3.6 & 12.8 & 12.2 & 0.0 & 0.0 & 0.0 & 0.1 \\
\hline Chlorite & 0.0 & 0.0 & 0.0 & 0.0 & 0.0 & 18.5 & 21.7 & 22.5 & 36.9 & 43.2 & 35.8 & 33.3 \\
\hline Total clay & 41.9 & 41.4 & 36.0 & 38.2 & 41.7 & 22.1 & 34.5 & 43.2 & 72.8 & 56.3 & 45.9 & 46.3 \\
\hline Total & 87.6 & 89.2 & 83.1 & 87.7 & 92.4 & 71.8 & 89.3 & 109.0 & 83.7 & 90.4 & 96.8 & 90.7 \\
\hline \multicolumn{13}{|c|}{ Biscaye's relative clay mineral composition } \\
\hline Kaolinite & 8.5 & 6.8 & 8.5 & 1.7 & 1.8 & 0.0 & 0.0 & 1.5 & 0.0 & 0.0 & 0.0 & 0.0 \\
\hline Smectite & 0.0 & 0.0 & 0.0 & 0.0 & 0.0 & 0.0 & 0.0 & 25.1 & 57.7 & 34.7 & 48.8 & 41.7 \\
\hline Illite & 91.5 & 93.2 & 91.5 & 98.3 & 98.2 & 6.8 & 14.9 & 11.7 & 0.0 & 0.0 & 0.0 & 0.0 \\
\hline Chlorite & 0.0 & 0.0 & 0.0 & 0.0 & 0.0 & 93.2 & 85.2 & 61.7 & 42.3 & 65.3 & 51.2 & 58.3 \\
\hline Total & 100.0 & 100.0 & 100.0 & 100.0 & 100.0 & 100.0 & 100.0 & 100.0 & 100.0 & 100.0 & 100.0 & 100.0 \\
\hline
\end{tabular}

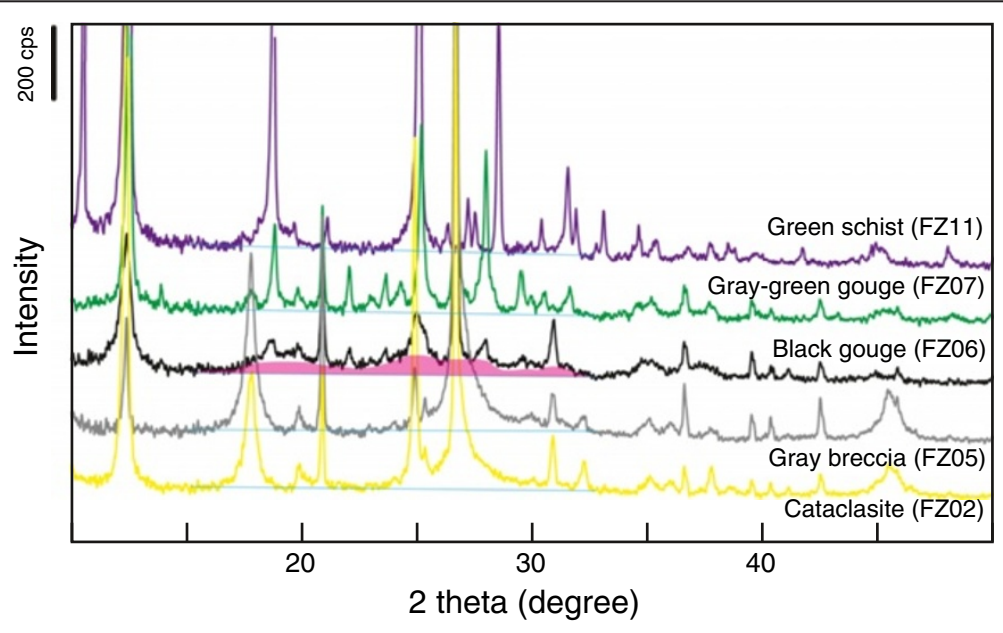

Figure 7 XRD patterns of samples on zero diffraction plates. These are compensated by subtracting the background intensity of the plate. Broad bumps at around $20^{\circ}$ to $30^{\circ} 2 \theta$ are shown by pink shading. 
(brecciated greenschist) have low $\mathrm{SiO}_{2}$ concentrations and high $\mathrm{Fe}_{2} \mathrm{O}_{3}$ and $\mathrm{MgO}$ concentrations (about 42 to 47, 13 to 15 , and 15 to 34 wt.\%, respectively). Similar compositional contrasts between samples FZ01 to FZ08 and samples FZ09 to FZ12 are also apparent in other major and trace element concentrations $\left(\mathrm{K}_{2} \mathrm{O}, \mathrm{Cr}, \mathrm{Ni}, \mathrm{Rb}, \mathrm{Cs}, \mathrm{Ba}, \mathrm{Pb}\right.$, and $\mathrm{Th}$ ) and in $\mathrm{Sr}$ isotope ratios (Table 1).

In the chondrite-normalized rare-earth element (REE) diagrams, samples FZ01 to FZ08 are clearly enriched in light REE (LREE), with weak to moderate negative Eu anomalies (Figure 8a). These REE patterns are typical of granitic rocks, and are consistent with those of Ryoke granites reported by Ishihara and Chappell (2007). Their high $\mathrm{SiO}_{2}$ and $\mathrm{Al}_{2} \mathrm{O}_{3}$ concentrations are also consistent with a diorite-granite composition.

In contrast, samples FZ09 to FZ12 are only moderately enriched in LREE. For these samples, REE patterns from $\mathrm{La}$ to $\mathrm{Sm}$ are flat or slightly depleted in La and Ce. REE concentrations of sample FZ09 are markedly lower than

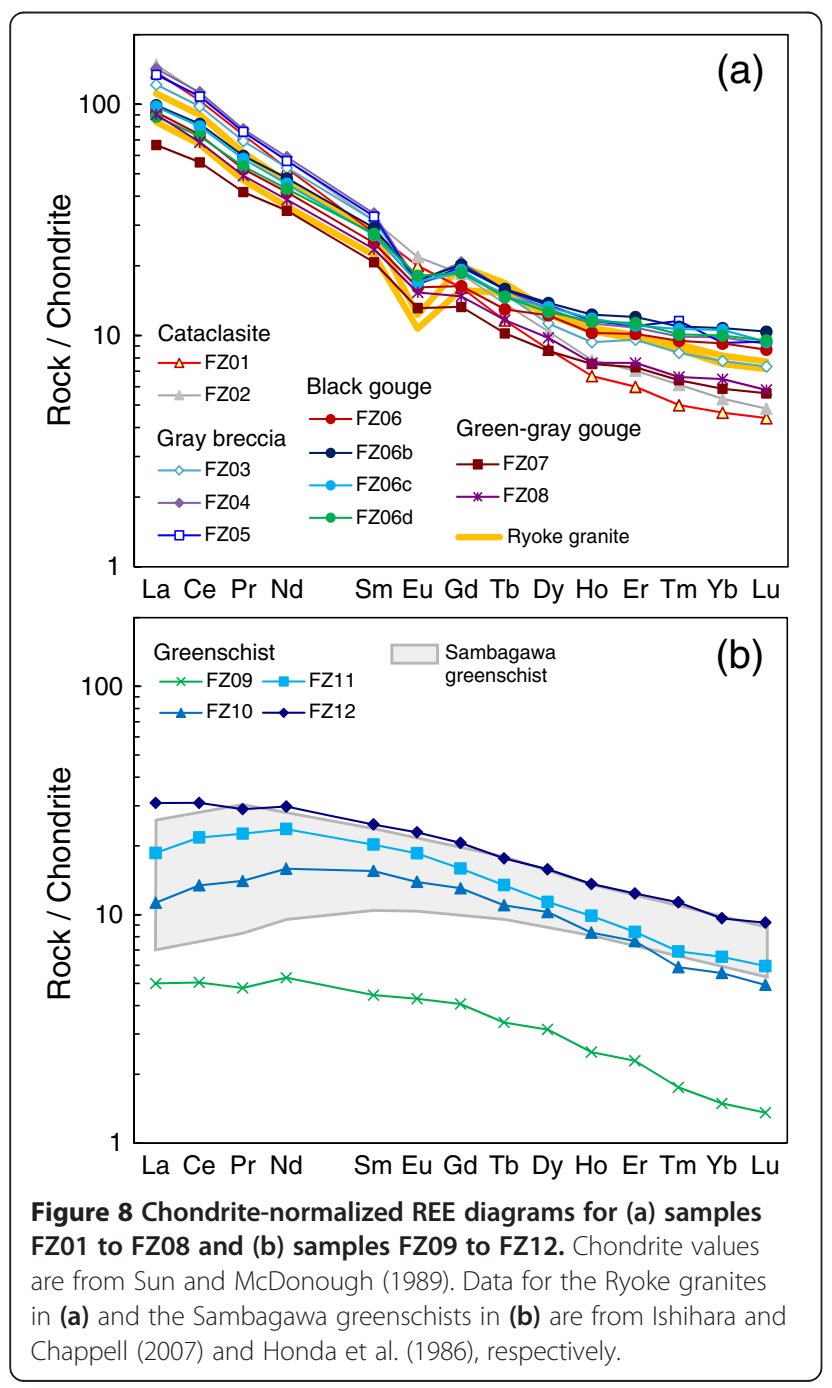

all other samples. These REE patterns (apart from sample FZ09) are consistent with those of normal or enriched mid-ocean ridge basalts (MORB) and MORB-type greenschists from the Sambagawa belt (Honda et al. 1986; Figure $8 \mathrm{~b}$ ). The low $\mathrm{SiO}_{2}$ and high $\mathrm{MgO}, \mathrm{Fe}_{2} \mathrm{O}_{3}, \mathrm{Cr}$, and $\mathrm{Ni}$ concentrations of these samples are also in accord with a basaltic origin. These observations suggest that samples FZ09 to FZ12 originated from accreted oceanic basalts. The extremely low REE concentrations of sample FZ09 can be attributed to entrainment of highly REE-depleted ultramafic clasts, which is supported by the high serpentinite content (Table 2) and very high $\mathrm{MgO}, \mathrm{Cr}$, and $\mathrm{Ni}$ concentrations in this sample.

The ${ }^{87} \mathrm{Sr} /{ }^{86} \mathrm{Sr}$ ratios of samples FZ01 to FZ08 (0.7070 to 0.7084 ) are consistent with those of Ryoke granites and gabbros reported previously (Kagami et al. 1985; Morioka et al. 2000; Okano et al. 2000; Kawamoto et al. 2013a). In contrast, samples FZ10 to FZ12 show distinctly low ${ }^{87} \mathrm{Sr} /{ }^{86} \mathrm{Sr}$ ratios (0.7032 to 0.7046$)$, which accord with those of MORB (0.7021 to 0.7054; Hoffman 2003). The relatively high ${ }^{87} \mathrm{Sr} /{ }^{86} \mathrm{Sr}$ ratio $(0.7066)$ obtained from sample FZ09 may reflect the involvement of an external source of $\mathrm{Sr}$ during serpentinization, or might be an aging effect. The high $\mathrm{Rb} / \mathrm{Sr}$ ratio of this sample $(0.0050$, cf. 0.0015 to 0.0039 for samples FZ10 to FZ12) reflects a rapid increase with time of the ${ }^{87} \mathrm{Sr} /{ }^{86} \mathrm{Sr}$ ratio of the sample because of decay of ${ }^{87} \mathrm{Rb}$ to ${ }^{87} \mathrm{Sr}$.

Thus, we concluded that the protoliths of samples FZ01 to FZ08 were the granitic rocks from the Ryoke belt and those of samples FZ09 to FZ12 were the greenschists of the Sambagawa belt.

\section{Discussion}

Anomalous mineral assemblage of the black gouge

The total mineral abundance (72\%) estimated by RockJock analysis of XRD data for black gouge sample FZ06 was much lower than those of the surrounding deformed rocks ( $83 \%$ to $109 \%$; Table 2$)$. This reflects the markedly lower total clay mineral abundance $(22 \%)$ of the black gouge than that of the surrounding Ryoke belt rocks (35\% to $43 \%$; Table 2). The XRD pattern of the black gouge, obtained by using the zero diffraction plate, confirmed the presence of broad low bumps at around $20^{\circ}$ to $30^{\circ} 2 \theta$ indicating the existence of amorphous phase (Figure 7). Furthermore, large amount of well-rounded spheroidal ultrafine particles ranging in size from submicrometer to several tens of nanometers, were observed only in the black gouge (Figure 5). Because weak X-ray diffraction intensity of minerals could be attributed not only to lattice distortions but also to reductions of particle size to the submicrometer to nanometer range (e.g., Lönnberg and Lundström 1994), the 'missing' mineral content in the XRD analysis of black gouge sample FZ06 could be attributed to the observed ultrafine particles. 
Such features resemble the characteristics of the latest slip zone within the Taiwan Chelungpu fault that slipped during the 1999 Chi-Chi earthquake (Hirono et al. 2014). The transformation of clay minerals (kaolinite and chlorite-ripidolite) into fully amorphous particles of several tens of nanometers in size has been confirmed by milling experiments (Vdovic et al. 2010), and such amorphous ultrafine particles have also been produced by friction experiments using quartzite, granite, and diorite (Yund et al. 1990; Hirose et al. 2012; Hirono et al. 2013). The Chelungpu fault comprises three dominant fault zones (Hirono et al. 2006, 2008), and the shallowest fault zone is most likely the one that slipped during the Chi-Chi earthquake because recent heating and a major stress-orientation anomaly were observed in that zone (Kano et al. 2006; Wu et al. 2007). Although aforementioned low total mineral abundance and ultrafine particles were observed in the latest slip zone of the Chelungpu fault, almost $100 \mathrm{wt} . \%$ total weight percentages of mineral abundance and no ultrafine particles were observed in all samples from two deeper fault zones. Hirono et al. (2014) suggested that amount of time elapsed after the 1999 Chi-Chi earthquake at the time that the samples were collected may have been insufficient for recrystallization to occur. Therefore, large amounts of ultrafine particles with weak X-ray diffraction intensity could be characteristics of the slip zone associated with the recent earthquake.

Taken together, the observations of this study and the results of previous studies suggest that anomalously low total mineral and total clay mineral abundances observed in the black gouge could be arisen from comminution during the recent earthquake.

\section{Anomalous elemental and isotope compositions of the black gouge}

The black gouge (FZ06), the most intensely deformed component of the fault zone, is developed within rocks of the Ryoke belt. To determine whether coseismic or interseismic processes are imprinted on the bulk chemical composition of sample FZ06, we need to examine the chemical heterogeneity of the original Ryoke belt rocks. The chemical composition of granitic rocks generally evolves as a result of differentiation of magma by crystal fractionation. Crystal fractionation causes systematic changes in the chemistry of the residual magma, and these changes reflect the affinities of different elements to the minerals that are crystallized. Therefore, the effect of magma differentiation on the Ryoke belt granitic rocks can be examined by using chemical variation diagrams. In Figure 9, major and trace element concentrations of the black gouge and various other samples are plotted against $\mathrm{Ti}, \mathrm{Nb}$, and $\mathrm{Nd}$ concentrations. The elements on the $x$-axis are chosen on the basis of their general solid/ melt bulk distribution coefficients (or 'incompatibility') of elements in magmatic systems (e.g., Sun and McDonough 1989) and their fluid immobility. The data for samples FZ01 to FZ05, FZ07, and FZ08, which originated from Ryoke belt granitic rocks, show either positive or negative correlations in Figure 9. These trends (solid lines in Figure 7) are consistent with those of granitic rocks, suggesting that the chemical variations of these samples are largely inherited from the granitic source rocks, but with variable degrees of differentiation. The $\mathrm{Sr}$ isotope ratios of these rocks also correlate well with $\mathrm{Nd}$ concentrations, which can be attributed to the combined effect of magma differentiation and ${ }^{87} \mathrm{Sr} /{ }^{86} \mathrm{Sr}$ evolution with time.

The black gouge samples (FZ06, FZ06b, FZ06c, and FZ06d) are indistinguishable from other Ryoke belt samples in terms of concentrations of $\mathrm{Ti}, \mathrm{Nb}, \mathrm{Nd}, \mathrm{Cs}$, $\mathrm{Ba}, \mathrm{La}, \mathrm{Sm}$, and $\mathrm{Pb}$ (Figure 9g,h,i,j,k). However, the black gouge samples are enriched in $\mathrm{Li}, \mathrm{MgO}, \mathrm{Cr}$, and $\mathrm{Ni}$, have a higher ${ }^{87} \mathrm{Sr} /{ }^{86} \mathrm{Sr}$ ratio, and are depleted in $\mathrm{Rb}$ and $\mathrm{Sr}$ (Figure 9a,b,c,d,e,f,l). Mg, Cr, and $\mathrm{Ni}$ are relatively fluid-immobile elements that are generally abundant in mafic rocks. As described in the previous section, the Sambagawa belt samples (FZ09 to FZ12) originated from basalt (with ultramafic clasts) and are highly enriched in these elements (Table 1). Thus, it is possible that the higher $\mathrm{MgO}, \mathrm{Cr}$, and $\mathrm{Ni}$ concentrations in the black gouge samples are the result of entrainment of small amounts of Sambagawa belt rocks. Indeed, the concentrations of $\mathrm{MgO}, \mathrm{Cr}$, and $\mathrm{Ni}$ (and of $\mathrm{Sr}, \mathrm{Cs}, \mathrm{Ba}, \mathrm{La}, \mathrm{Sm}, \mathrm{Pb}, \mathrm{Ti}, \mathrm{Nb}$, and $\mathrm{Nd}$ ) in the black gouge samples can be explained by a source comprising about 70\% Ryoke (FZ04) and $30 \%$ Sambagawa (FZ10) rocks (Figure 9). The $\mathrm{SiO}_{2}, \mathrm{Al}_{2} \mathrm{O}_{3}$, and $\mathrm{Fe}_{2} \mathrm{O}_{3}$ contents of the mixed product $(63.1,14.6$, and $7.2 \mathrm{wt} . \%$, respectively) are also comparable to those of sample FZ06 (63.0, 14.5, and $7.7 \mathrm{wt} . \%$, respectively). We concluded that the chemical composition of the black gouge from this outcrop has been modified by entrainment of Sambagawa belt rocks during deformation associated with MTL activity.

Even if the effect of source-rock mixing is taken into account, the concentrations of $\mathrm{Li}$ and $\mathrm{Rb}$ and the $\mathrm{Sr}$ isotope ratio of the black gouge samples remain anomalous (Figure 7). $\mathrm{Li}, \mathrm{Rb}$, and $\mathrm{Sr}$ are known to be fluid-mobile elements, and mobilization and isotope exchange of these elements by coseismic high-temperature fluid-rock interactions has been recognized in the slip zones of the faults of Chelungpu, Boso, and Shimanto (Ishikawa et al. 2008; Hamada et al. 2011; Honda et al. 2011).

To quantify the possible enrichment or depletion of elements in the black gouge samples as a result of fluid-rock interactions, we estimated the source-rock compositions of the FZ06 samples. Here, we assumed that the original trace element composition of the precursor to the black gouge lay along the mixing line between samples FZ04 and FZ10, which best explains the fluid-immobile 


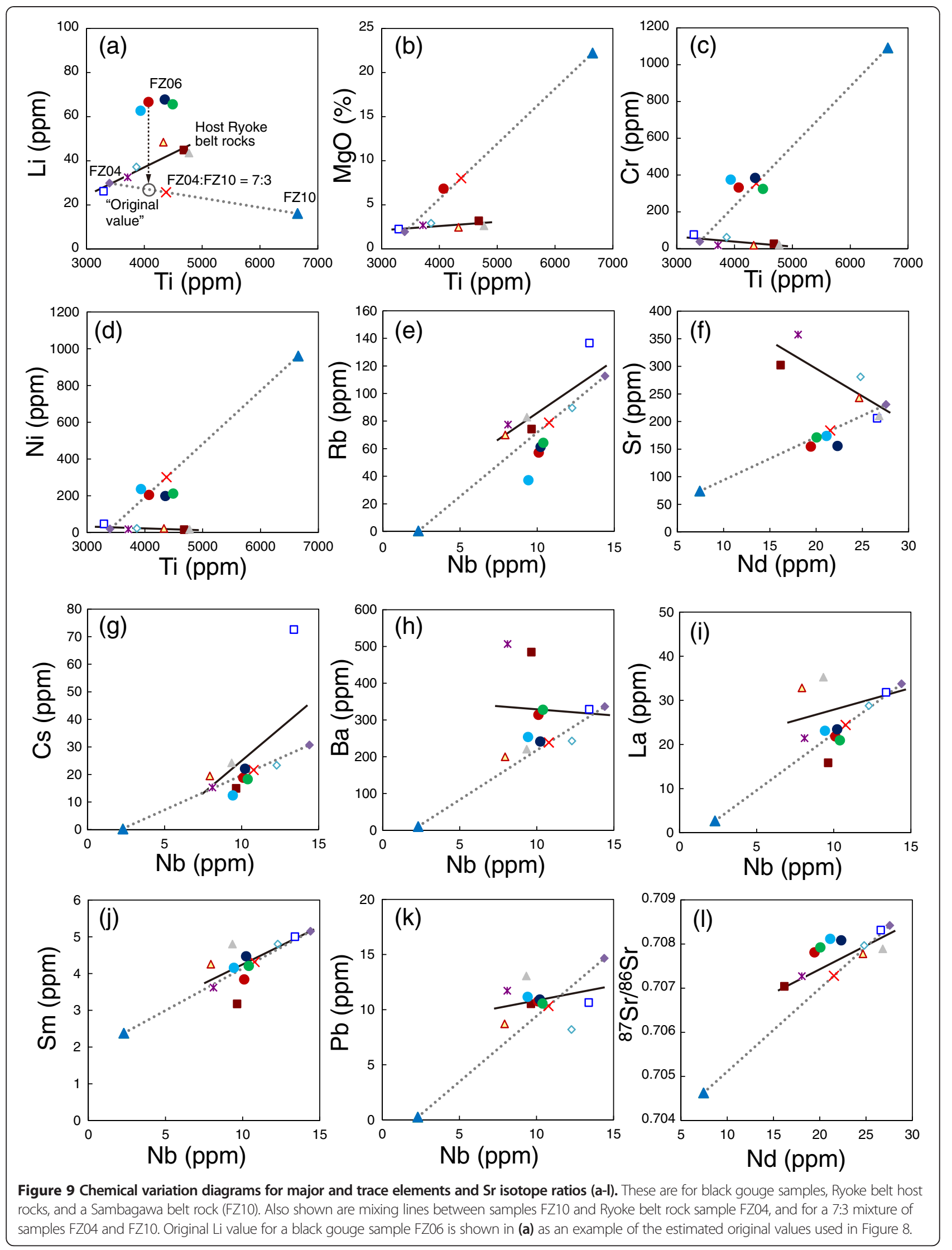


major and trace element characteristics of the FZ06 samples (Figure 9). Then, by assuming that $\mathrm{Ti}, \mathrm{Nb}$, and $\mathrm{Nd}$ were immobile during fluid-related processes, we estimated the original element concentrations in each FZ06 sample according to the mixing line (see Figure 9a). The trace element concentrations of the FZ06 samples normalized to their inferred original values are shown in Figure 10. Considering the heterogeneity of the Ryoke belt rocks (1 SD error bars in Figure 10), only the normalized values for $\mathrm{Li}, \mathrm{Be}, \mathrm{Zn}, \mathrm{W}$ (and some $\mathrm{Rb}$ values), and the ${ }^{87} \mathrm{Sr} /{ }^{86} \mathrm{Sr}$ ratio deviate markedly from the inferred original values. The enrichments of $\operatorname{Li}(130 \%$ to $160 \%)$, Be $(80 \%$ to $130 \%)$ and ${ }^{87} \mathrm{Sr} /{ }^{86} \mathrm{Sr}$ ratio $\left(90 \times 10^{-3} \%\right.$ to $\left.130 \times 10^{-3} \%\right)$ are considerable. It is possible that these enrichments have been overestimated because of uncertainty about the composition of the Sambagawa belt rocks entrained in the black gouge. If we define the compositional anomaly as the deviation from the magma differentiation trends of the host Ryoke belt rocks (solid lines in Figure 9) rather than the deviation from the FZ04 to FZ10 mixing line, then the enrichments of $\mathrm{Li}, \mathrm{Be}$, and ${ }^{87} \mathrm{Sr} /{ }^{86} \mathrm{Sr}$ are $51 \%$ to $75 \%, 25 \%$ to $63 \%$, and $57 \times 10^{-3} \%$ to $79 \times 10^{-3} \%$, respectively, which are still considerably beyond the heterogeneity of the host rocks shown in Figure 10. Considering the generally low $\mathrm{Li}$ and $\mathrm{Be}$ concentrations and the low ${ }^{87} \mathrm{Sr} /{ }^{86} \mathrm{Sr}$ ratios of the Sambagawa belt rocks (Table 1), the estimated enrichments based on the magma differentiation trend should be regarded as lower limits.

The above chemical characteristics of the black gouges could be produced by preferential uptake or extraction of elements associated with fluid-rock interactions. The enrichments of $\mathrm{Li}$ and ${ }^{87} \mathrm{Sr} /{ }^{86} \mathrm{Sr}$ observed here for MTL black gouge samples contrast strikingly with depletions of $\mathrm{Li}$ and ${ }^{87} \mathrm{Sr} /{ }^{86} \mathrm{Sr}$ observed in the Chelungpu fault black gouges (Ishikawa et al. 2008). These differences imply that fluid-rock interactions occurred under considerably different conditions in the two regions.

\section{Element distribution modeling for high-temperature fluid-rock interactions}

To quantify the effect of fluid-rock interaction in the black gouge, we applied the simple model of Ishikawa et al. (2008). Assuming chemical equilibrium, the solid/ fluid bulk distribution coefficient $(\mathrm{Kd})$ of a trace element is defined by

$$
\mathrm{Kd}=\frac{C_{\mathrm{s}}}{C_{\mathrm{f}}}
$$

where $C_{\mathrm{s}}$ and $C_{\mathrm{f}}$ are element concentrations (ppm) in the solid and fluid, respectively. Here, we assume interaction of a solid with a single batch of fluid. When we define the fluid/solid mass ratio, $R$, mass balance requires that

$$
C_{\mathrm{s}}+R \cdot C_{\mathrm{f}}=C_{\mathrm{s} 0}+R \cdot C_{\mathrm{f} 0}
$$

where $C_{\mathrm{s} 0}$ and $C_{\mathrm{f} 0}$ are the element concentrations in the solid and fluid, respectively, prior to solid-fluid interaction. From Equations 1 and 2, we obtain

$$
C_{\mathrm{s}}=\mathrm{Kd} \cdot \frac{C_{\mathrm{s} 0}+R \cdot C_{\mathrm{f} 0}}{R+\mathrm{Kd}}
$$

from which we can calculate the trace element concentration of the solid after interaction with the fluid.

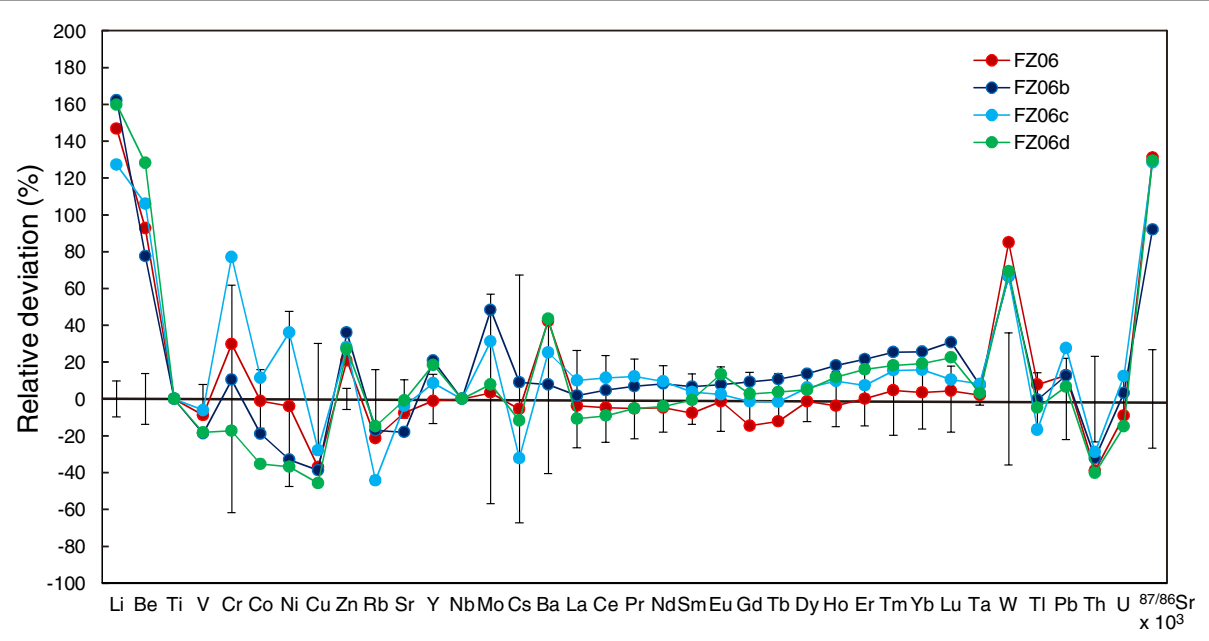

Figure 10 Trace element and Sr isotope compositions of black gouge samples normalized to original values. Original values were estimated from mixing lines between samples FZO4 and FZ10, and Ti, Nb, and Nd concentrations of black gouge samples. Relative deviation (\%) of each element concentration from the original value was calculated as follows: [(Concentration in black gouge - Original value)/Original value] $\times 100$. Error bars indicate standard deviations from the data for Ryoke belt host rocks and are representative of the chemical heterogeneities of source rock compositions. 
Sr isotope ratios in solids and fluids are identical under equilibrium conditions, so the $\mathrm{Sr}$ isotope ratio in the solid after interaction with the fluid, $\left({ }^{87} \mathrm{Sr} /{ }^{86} \mathrm{Sr}\right)_{\mathrm{s}}$, is given by

$$
\begin{aligned}
\left({ }^{87} \mathrm{Sr} /{ }^{86} \mathrm{Sr}\right)_{s}= & \left({ }^{87} \mathrm{Sr} /{ }^{86} \mathrm{Sr}\right)_{s 0} \cdot \frac{C_{\mathrm{s} 0 \mathrm{Sr}}}{C_{\mathrm{s} 0 \mathrm{Sr}}+R \cdot C_{\mathrm{f} 0 \mathrm{Sr}}} \\
& +\left({ }^{87} \mathrm{Sr} /{ }^{86} \mathrm{Sr}\right)_{f 0} \cdot \frac{R \cdot C_{\mathrm{f} 0 \mathrm{Sr}}}{C_{\mathrm{s} 0 \mathrm{Sr}}+R \cdot C_{\mathrm{f} 0 \mathrm{Sr}}}
\end{aligned}
$$

where $\left({ }^{87} \mathrm{Sr} /{ }^{86} \mathrm{Sr}\right)_{\mathrm{s} 0}$ and $\left({ }^{87} \mathrm{Sr} /{ }^{86} \mathrm{Sr}\right)_{\mathrm{fo}}$ are the $\mathrm{Sr}$ isotope ratios in the solid and fluid, respectively, prior to solidfluid interaction.

In our calculations, we used the estimated original values of the FZ06 samples (Figure 10 and Table 3) for $C_{\mathrm{s} 0}$ and $\left({ }^{87} \mathrm{Sr} /{ }^{86} \mathrm{Sr}\right)_{\mathrm{s} 0}$. For realistic calculations, however, the values of $\mathrm{Kd}, C_{\mathrm{fO}}$, and $\left({ }^{87} \mathrm{Sr} /{ }^{86} \mathrm{Sr}\right)_{\mathrm{fo}}$ appropriate for the MTL fault are also required. $\mathrm{Kd}$ can be estimated on the basis of the results of a hydrothermal experiment for sediments from the Escanaba Trough by James et al. (2003). Although the MTL is not a sediment-hosted fault system, the chemical and mineral compositions of the granite-derived fault gouges of our study are similar to those of James et al. (2003) - hemipelagic-terrigeneous sediments with $\mathrm{SiO}_{2}=59.3$ wt.\%, $\mathrm{Al}_{2} \mathrm{O}_{3}=14.1$ wt.\%, $\mathrm{Fe}_{2} \mathrm{O}_{3}=6.43$ wt.\%, $\mathrm{CaO}=4.23$ wt.\%, and $\mathrm{K}_{2} \mathrm{O}=1.96$ wt.\%. Thus, it is reasonable to apply the sediment-based $\mathrm{Kd}$ values to our model calculations. The $\mathrm{Kd}$ values estimated for temperatures of $100^{\circ} \mathrm{C}, 150^{\circ} \mathrm{C}, 200^{\circ} \mathrm{C}$, $300^{\circ} \mathrm{C}$, and $350^{\circ} \mathrm{C}$ are shown in Table 3 . We estimated values of $C_{\mathrm{fo}}$ and $\left({ }^{87} \mathrm{Sr} /{ }^{86} \mathrm{Sr}\right)_{\mathrm{fo}}$ from the compositions of surface flows from natural mineral springs along the MTL. Spring waters from Kashio (Figure 1) are representative of those along the MTL. They are saline, with Arima-type chemical compositions (e.g., Hashizume 1984), and are thought to be derived from deep in the crust or from the subducting slab (Kawamoto et al. 2013b). Major and trace element analyses by ICP-MS and ICP-AES of spring waters from Kashio, Toyama (20 km southwest of Anko), and Yamamuro (35 km north of Anko) revealed tight linear correlations of trace element concentrations with $\mathrm{Na}$ concentrations (Figure 11), suggesting that these MTL fluids share similar chemical characteristics that are essentially controlled by mixing of saline end-component fluids with meteoric water. Here, we used a moderate fluid composition with a Na concentration of 1,000 ppm (Figure 11) estimated from Kashio spring water to calculate $C_{\mathrm{fo}}$ and $\left({ }^{87} \mathrm{Sr} /{ }^{86} \mathrm{Sr}\right)_{\mathrm{fo}}$ values (Table 3 ). The fluid so estimated is characterized by a much higher $\mathrm{Li} / \mathrm{Na}$ ratio $\left(7.3 \times 10^{-3}\right)$ than that of seawater $\left(1.5 \times 10^{-5}\right)$.

If the values of $C_{\mathrm{s} 0}, C_{\mathrm{fo}},\left({ }^{87} \mathrm{Sr} /{ }^{86} \mathrm{Sr}\right)_{\mathrm{s} 0}$, and $\left({ }^{87} \mathrm{Sr} /{ }^{86} \mathrm{Sr}\right)_{\mathrm{fo}}$ are constant (Equations 3 and 4), the calculated composition of the rock after interaction with the fluid is dependent on the $\mathrm{Kd}$ values and the fluid/solid mass ratio $R$. Because $\mathrm{Kd}$ for each element varies as a function of temperature, the calculated composition depends on both temperature and $R$. The results of calculations for temperatures of $100^{\circ} \mathrm{C}, 150^{\circ} \mathrm{C}, 200^{\circ} \mathrm{C}, 250^{\circ} \mathrm{C}, 300^{\circ} \mathrm{C}$, and $350^{\circ} \mathrm{C}$ are shown in Figure 12. These calculations indicate that $\mathrm{Li}$ concentrations and ${ }^{87} \mathrm{Sr} /{ }^{86} \mathrm{Sr}$ ratios would have been preferentially elevated in the black gouge by interaction with fluids at temperatures between $100^{\circ} \mathrm{C}$ and $250^{\circ} \mathrm{C}$. The calculated compositions best fit the observed values for sample FZ06 (red solid circles in Figure 12) at $150^{\circ} \mathrm{C}$ and $R=7$, at $200^{\circ} \mathrm{C}$ and $R=8$, and at $250^{\circ} \mathrm{C}$ and $R=14$. At temperatures higher than $300^{\circ} \mathrm{C}$, increases of the $\mathrm{Li}$ deviation are restricted by the rapid decrease of $\mathrm{Kd}_{\mathrm{Li}}$ with increasing temperature (Table 3). When we use the minimum values for $\mathrm{Li}$ and ${ }^{87} \mathrm{Sr} /{ }^{86} \mathrm{Sr}$ estimated for the FZ06 samples (red open circles in Figure 12; deviation from the magma differentiation trends of the host Ryoke belt rocks), they best fit the calculated values at $250^{\circ} \mathrm{C}$ and $R=4$. Even if we modify the $C_{\mathrm{f} 0}$ values along the

\begin{tabular}{|c|c|c|c|c|c|c|c|c|c|c|c|}
\hline & \multicolumn{6}{|c|}{ Kd } & \multirow{2}{*}{$\begin{array}{c}C_{\mathrm{fo}} \\
(\mathrm{ppm})\end{array}$} & \multirow{2}{*}{$\begin{array}{c}C_{\mathrm{s} 0} \mathrm{FZ06} \\
(\mathrm{ppm})\end{array}$} & \multirow{2}{*}{$\begin{array}{c}C_{\mathrm{s} 0} \mathrm{FZ06b} \\
(\mathrm{ppm})\end{array}$} & \multirow{2}{*}{$\begin{array}{c}C_{\mathrm{so}} \mathrm{FZO6c} \\
(\mathrm{ppm})\end{array}$} & \multirow{2}{*}{$\begin{array}{c}C_{\mathrm{s} 0} \mathrm{FZ} 06 \mathrm{~d} \\
(\mathrm{ppm})\end{array}$} \\
\hline & $100^{\circ} \mathrm{C}$ & $150^{\circ} \mathrm{C}$ & $200^{\circ} \mathrm{C}$ & $250^{\circ} \mathrm{C}$ & $300^{\circ} \mathrm{C}$ & $350^{\circ} \mathrm{C}$ & & & & & \\
\hline Cs & 1,800 & 440 & 180 & 92 & 59 & 26 & 0.0085 & 19.9 & 20.2 & 18.2 & 20.7 \\
\hline $\mathrm{Rb}$ & 423 & 210 & 120 & 81 & 67 & 25 & 0.039 & 72.7 & 73.9 & 66.5 & 75.5 \\
\hline $\mathrm{Ba}$ & 130 & 89 & 52 & 20 & 17 & 14 & 4.7 & 221 & 224 & 203 & 229 \\
\hline La & 15,000 & 80,000 & 19,000 & 41,000 & 47,000 & 26,000 & 0.00007 & 22.7 & 23.0 & 21.0 & 23.5 \\
\hline $\mathrm{Pb}$ & 10,000 & 13,000 & 4,500 & 1,900 & 350 & 110,000 & 0.00079 & 9.53 & 9.68 & 8.74 & 9.89 \\
\hline Sr & 26 & 22 & 19 & 16 & 17 & 20 & 9.5 & 167 & 190 & 181 & 172 \\
\hline Sm & 140,000 & 81,000 & 19,000 & 41,000 & 47,000 & 26,000 & 0.00008 & 4.16 & 4.19 & 4.01 & 4.23 \\
\hline Li & 100 & 53 & 32 & 15 & 8.4 & 2.8 & 7.3 & 27.0 & 25.8 & 27.6 & 25.2 \\
\hline${ }^{87} \mathrm{Sr} /{ }^{86} \mathrm{Sr}$ & & & & & & & $\left({ }^{87} \mathrm{Sr} /{ }^{86} \mathrm{Sr}\right)_{\mathrm{fo}}$ & $\left({ }^{87} \mathrm{Sr} /{ }^{86} \mathrm{Sr}\right)_{\mathrm{sO}}$ & $\left({ }^{87} \mathrm{Sr} /{ }^{86} \mathrm{Sr}\right)_{\mathrm{sO}}$ & $\left({ }^{87} \mathrm{Sr} /{ }^{86} \mathrm{Sr}\right)_{\mathrm{sO}}$ & $\left({ }^{87} \mathrm{Sr} /{ }^{86} \mathrm{Sr}\right)_{\mathrm{sO}}$ \\
\hline & & & & & & & 0.70917 & 0.70689 & 0.70743 & 0.70721 & 0.70701 \\
\hline
\end{tabular}

Table 3 Parameters used for modeling of trace-element compositions and Sr isotope ratio of the black fault gouge

Kd values of Cs, Rb, Ba Sr and Li are calculated from James et al. (2003). Kd values for other elements are from You et al. (1996). 


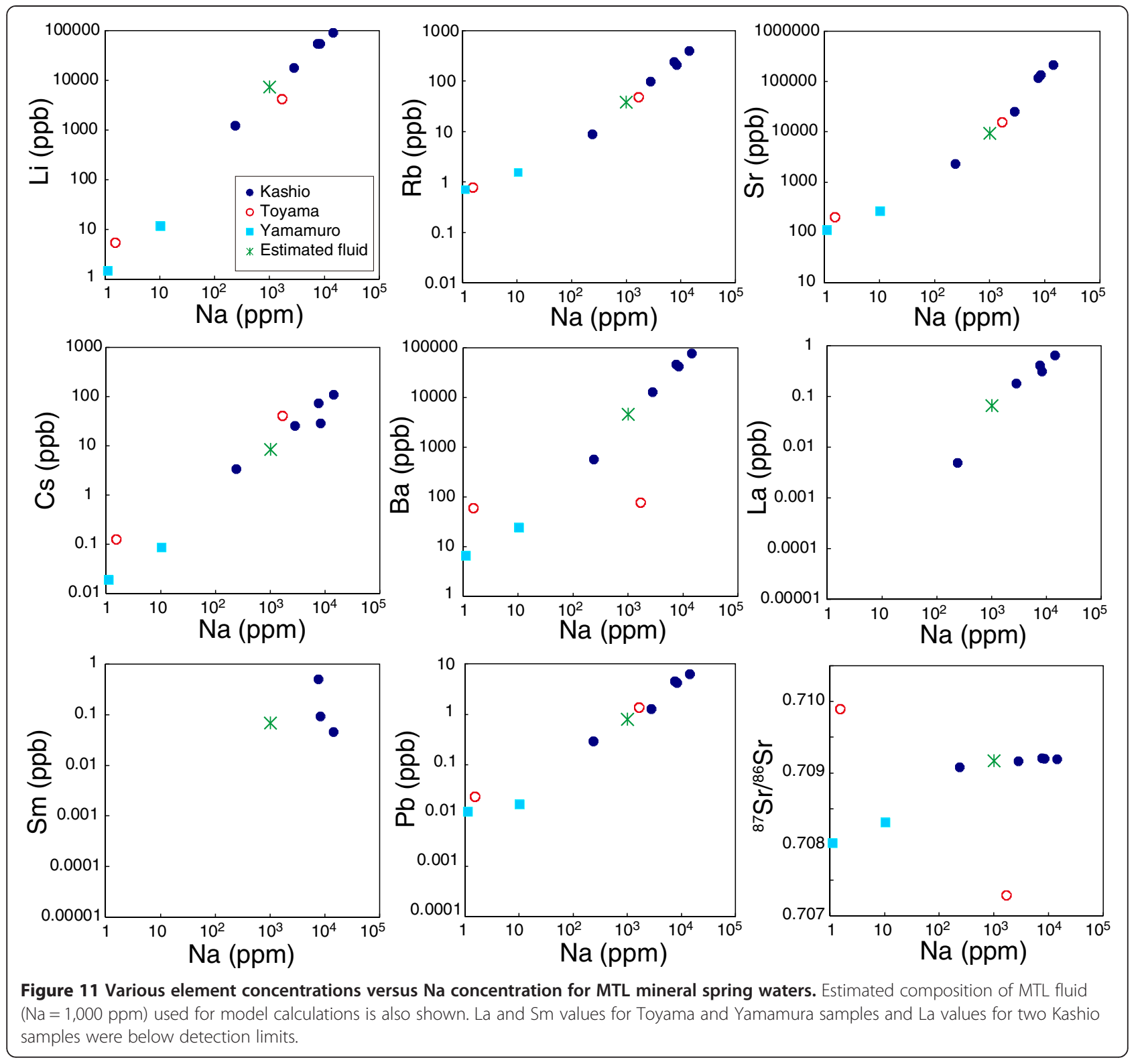

trends defined by the data for MTL fluids (Figure 11), the calculation results are essentially similar and the best-estimated $R$ value varies according to the value of $C_{\mathrm{fo}}$. Calculations using a suite of $\mathrm{Kd}$ values from experimental hydrothermal data from Nankai Trough sediments (You et al. 1996) also gave similar results. These modeling results therefore suggest that the chemical characteristics of the black gouge are a result of fluid-rock interactions at temperatures up to $250^{\circ} \mathrm{C}$.

Our XRD analysis also shows that black gouge sample FZ06 contained K-feldspar and chlorite (Figure 6 and Table 1), which are typical secondary minerals formed by hydrothermal alteration. The development of black chlorite-bearing seams within the intense foliation in the black gouge indicate that chlorite was precipitated during or after shearing. Jefferies et al. (2006) also reported precipitation of fibrous chlorite within MTL cataclasites at the onset of grain-scale brittle deformation. These results and observations support the scenario for occurrence of high-temperature fluids in the black gouge inferred from geochemical data.

The temperatures of up to $250^{\circ} \mathrm{C}$ during fluid-rock interactions in the black gouge are unlikely to have been attained without earthquake-associated frictional heating or influx of a hot transient pulse of fluid, which could result from post-seismic discharge from deep rupture zones. The occurrence of fluid-induced geochemical anomaly is restricted within the black gouge zone that is characterized by a large amount of ultrafine particles and weak X-ray diffraction intensity. This strongly suggests 


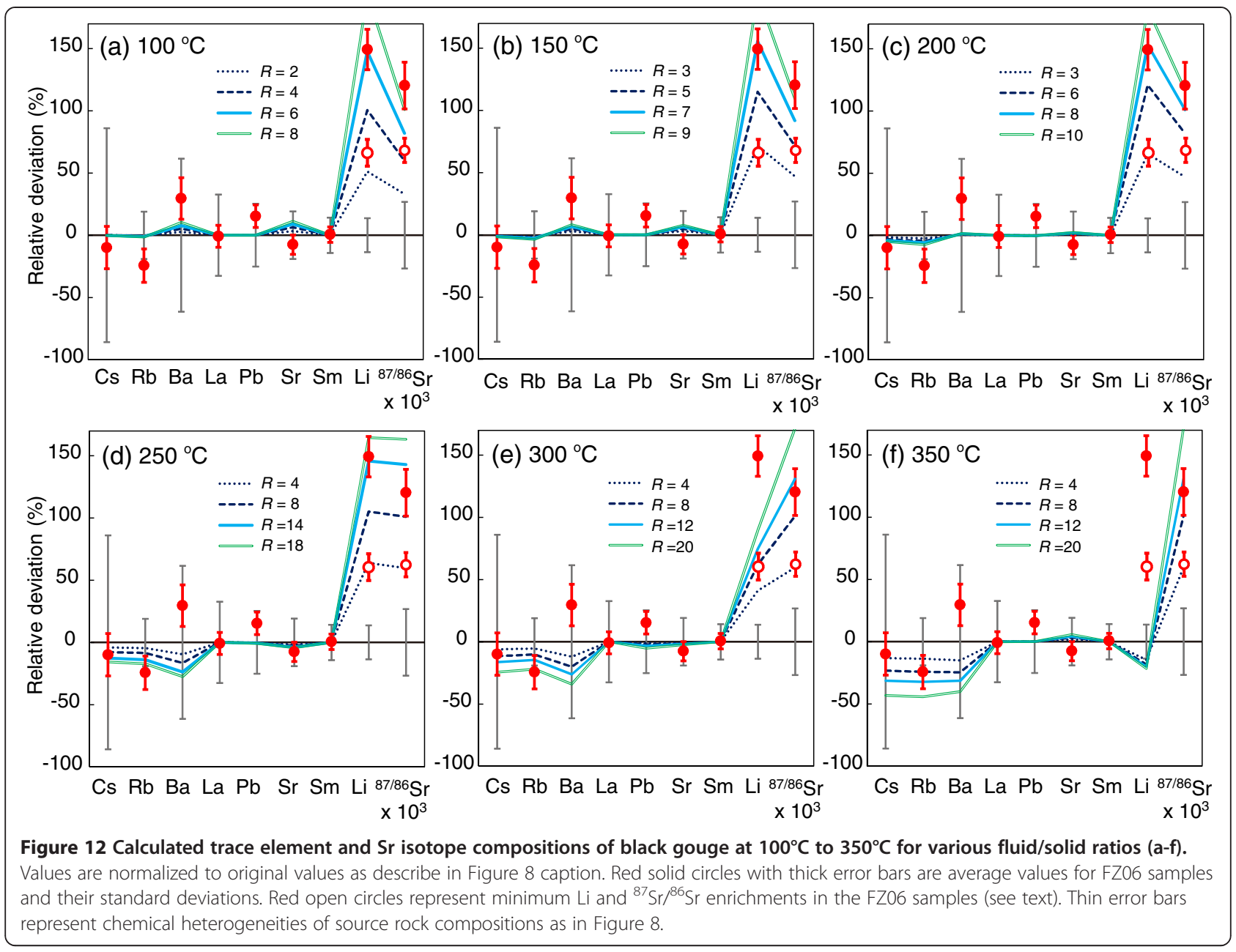

that the high temperature resulted from earthquake slip. Although the fluid-rock interactions require some local flow or circulation of fluids, lack of extensive veins developed along the black gouge zone (Figure 3) is indicative of fluid-rock interactions induced by frictional heating, not by the hot transient pulse of fluid or hydrothermal alteration at the depths.

\section{Kinetic evaluation of the geochemical signals recorded in the black gouge}

When coseismic fluid-rock interactions take place in a fault zone, the rocks in the fault zone may not record clear geochemical signals of these interactions. This is because the duration of a single earthquake event may be shorter than the time required for such reactions to take place, particularly if reaction rates are slow because of relatively low temperatures. Thus, kinetic effects must be taken into consideration to achieve a rigorous evaluation of fluid-rock interactions during an earthquake (e.g., Ishikawa et al. 2008). The degree to which fluid-solid chemical (isotopic) equilibrium $(F)$ is achieved according to Beck et al. (1992) is

$$
F=1-\exp \left(-\frac{C_{\mathrm{s}}}{C_{\mathrm{f}}} \frac{A}{M} k t\right)
$$

where $C_{\mathrm{s}} / C_{\mathrm{f}}$ is the ratio of a trace element concentration in the solid to that in the fluid, $A / M$ is the ratio of solid surface area to fluid mass, $k$ is the reaction rate, and $t$ is time. Only limited data are available for $k$ values associated with trace element equilibration. The reported $k$ values for $\mathrm{Sr}$ isotope exchange during calcite recrystallization at $300^{\circ} \mathrm{C}, 350^{\circ} \mathrm{C}$, and $400^{\circ} \mathrm{C}$ are $4.68 \times 10^{-9}$, $2.82 \times 10^{-8}$, and $1.32 \times 10^{-7} \mathrm{~mol} \mathrm{~m}^{-2} \mathrm{~s}^{-1}$, respectively (Beck et al. 1992), and the extrapolated $k$ value at $150^{\circ} \mathrm{C}$ is $1.62 \times 10^{-12} \mathrm{~mol} \mathrm{~m}^{-2} \mathrm{~s}^{-1}$. We derived a value of 19 for $C_{\mathrm{s}} / C_{\mathrm{f}}$ from the $C_{\mathrm{s} 0}$ and $C_{\mathrm{f} 0}$ values for $\mathrm{Sr}$ in Table 3 , and estimated $A / M$ by assuming $A=3.23 \times 10^{7} \mathrm{~m}^{2} \mathrm{~m}^{-3}$, the value determined by $\mathrm{Ma}$ et al. (2006) for fault gouge from the Chelungpu fault, and $10 \mathrm{MPa}$ fluid pressure and $20 \%$ porosity. 
Element partitioning within the fault zone may be controlled by complicated processes that reflect the interaction of fluids with multiple mineral phases, and it is not clear what $F$ values we require to detect the geochemical signal derived from fluid-rock interactions. However, if the parameters we assumed here are valid, then $99 \%, 90 \%$, and $50 \%$ equilibrium can be achieved at $250^{\circ} \mathrm{C}$ in $2.1 \times 10^{3}, 1.1 \times 10^{3}$, and $3.3 \times 10^{2} \mathrm{~s}$, respectively; at $200^{\circ} \mathrm{C}$ in $3.0 \times 10^{4}, 1.6 \times 10^{4}$, and $4.9 \times 10^{3} \mathrm{~s}$, respectively; and at $150^{\circ} \mathrm{C}$ in $7.8 \times 10^{5}, 4.2 \times 10^{5}$, and $1.3 \times 10^{5} \mathrm{~s}$, respectively. Thus, near- or quasi-equilibrium requires heat for a longer duration than can be provided by a single earthquake event, especially the durations required at temperatures of $200^{\circ} \mathrm{C}$ and $150^{\circ} \mathrm{C}$. Although the temperature in a fault during a single earthquake event varies with time in response to frictional heating and heat conduction, because $k$ decreases rapidly as cooling proceeds, it is likely that only the geochemical signals that represent the peak temperatures reached are recorded in the fault rocks.

Here, we have assumed that repeated earthquake events simply result in an increase of the net reaction time for fluid-rock interactions. Figure 13a,b,c shows the relationships between the number of earthquake events and the heat duration required to attain $F$ of $0.99,0.90,0.50$, and 0.20 at constant temperatures of $250^{\circ} \mathrm{C}, 200^{\circ} \mathrm{C}$, and $150^{\circ} \mathrm{C}$. Even if we assume events of relatively long duration, for example $5 \mathrm{~min}$ each, $90 \%$ equilibrium requires 4, 53, and 1,400 earthquake events at temperatures of $250^{\circ} \mathrm{C}$, $200^{\circ} \mathrm{C}$, and $150^{\circ} \mathrm{C}$, respectively. Thus, it is clear that the geochemical anomaly in the black gouge requires multiple earthquake events, unless the reaction rate in the MTL fault was considerably faster than our estimates. Although the MTL activity in this area has not been well understood, if the occurrence of thousands of earthquake events in this fault zone is unrealistic, earthquake events at temperatures higher than $200^{\circ} \mathrm{C}$ are required.

It should be noted that the achievement of fluid-rock near-equilibrium in a short time period requires very large solid surface area. For instance, if we assume smaller $A$ of $1.0 \times 10^{6} \mathrm{~m}^{2} \mathrm{~m}^{-3}$, which represents the value for very fine-grained sediments, it takes much longer time, $1.4 \times 10^{4}$ and $2.0 \times 10^{5} \mathrm{~s}$ at $250^{\circ} \mathrm{C}$ and $200^{\circ} \mathrm{C}$, respectively, to achieve $90 \%$ equilibrium with the same parameters described above. This implies that fluid-rock interactions coupled with dynamic production of ultrafine solid grains as well as frictional heating during the earthquake slip

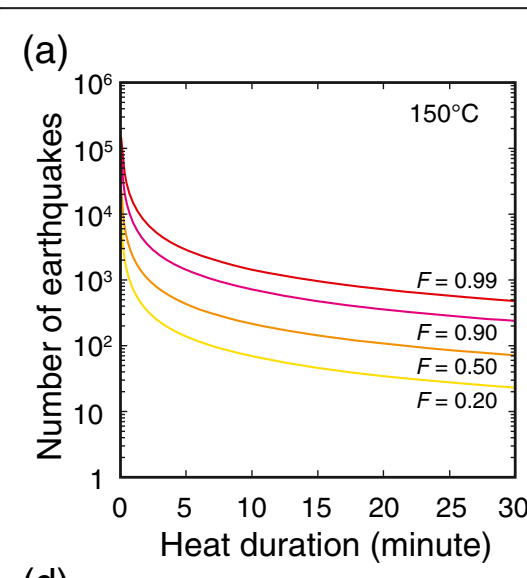

(d)

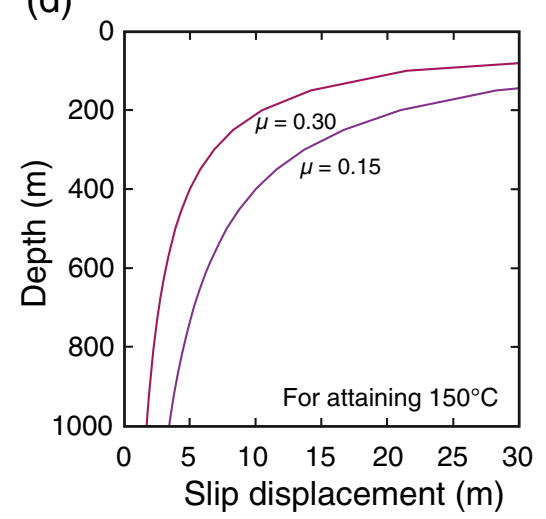

(b)

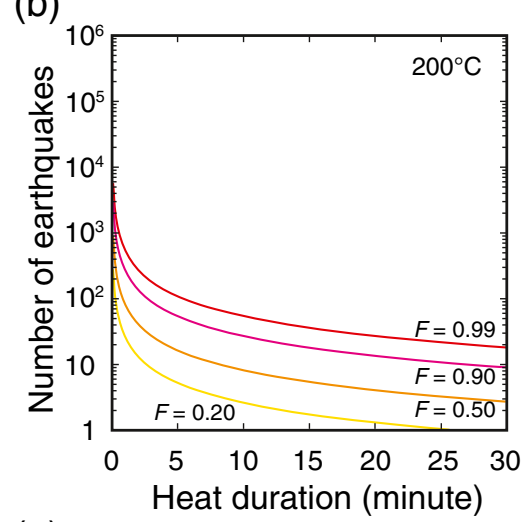

(e)

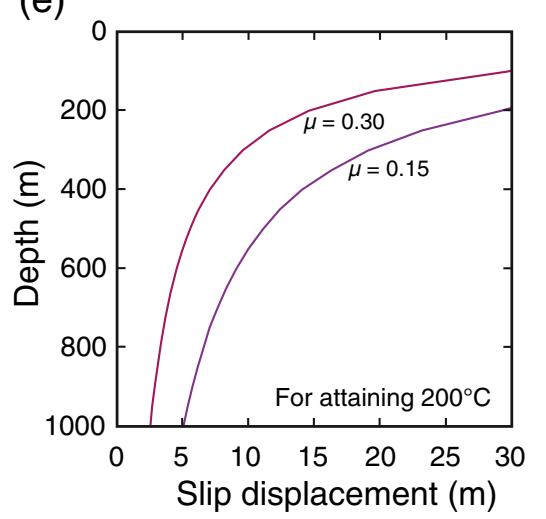

(c)

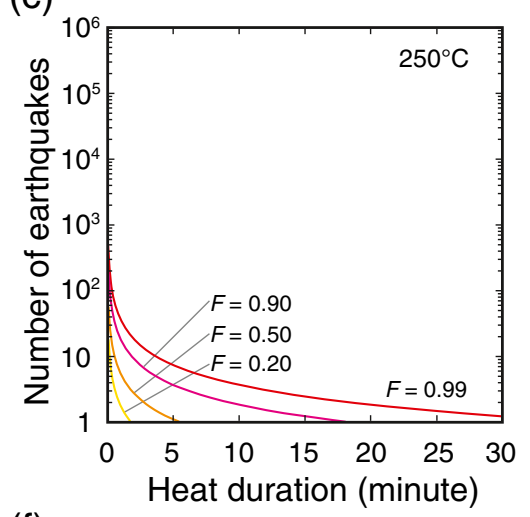

(f)

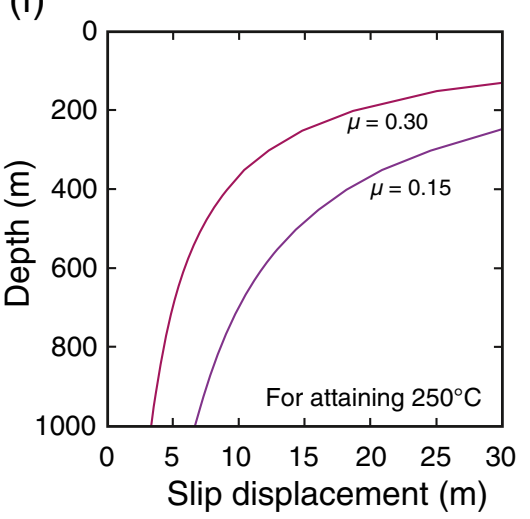

Figure 13 Relationships between heat duration and number of earthquake events (a-c) and between slip displacement and depth (d-f). (a-c) $F=0.20,0.50,0.90$, and 0.99 at temperatures of $150^{\circ} \mathrm{C}, 200^{\circ} \mathrm{C}$, and $250^{\circ} \mathrm{C}$. (d,e,f) These parameters are required to attain temperatures of $150^{\circ} \mathrm{C}, 200^{\circ} \mathrm{C}$, and $250^{\circ} \mathrm{C}$ by frictional heating. 
are essential to satisfy the physicochemical condition under which the high-temperature geochemical signals as observed in the black gouge become detectable.

\section{Earthquake slip along the MTL at the Anko section}

The tectonic conditions under which temperatures of $150^{\circ} \mathrm{C}$ to $250^{\circ} \mathrm{C}$ are reached during earthquake slip can be simply constrained by the relationships among depth, slip displacement, and frictional coefficient in the fault gouge. Here, we assumed $2.70 \mathrm{~g} \mathrm{~cm}^{-3}$ bulk density, $1.20 \mathrm{~J} \mathrm{~g}^{-1} \mathrm{~K}^{-1}$ specific heat capacity, no thermal diffusion, $30^{\circ} \mathrm{C} \mathrm{km}^{-1}$ geothermal gradient, $15^{\circ} \mathrm{C}$ groundsurface temperature, and hydrostatic confining stress (normal stress on the slip zone equal to overburden stress). The combinations of depth and slip displacement required to attain temperatures of $150^{\circ} \mathrm{C}, 200^{\circ} \mathrm{C}$, and $250^{\circ} \mathrm{C}$ for friction coefficients 0.30 and 0.15 are shown in Figure $13 \mathrm{~d}, \mathrm{e}, \mathrm{f}$. For frictional heating of $200^{\circ} \mathrm{C}$ to $250^{\circ} \mathrm{C}$, slip displacement of more than $15 \mathrm{~m}$ is required at shallow depths (e.g., $200 \mathrm{~m}$ ), whereas a shorter displacement of $<10 \mathrm{~m}$ would attain higher temperatures at greater depth (e.g., $600 \mathrm{~m}$ ). Considering that other recent inland earthquakes have not had displacements as large as $15 \mathrm{~m}$ (e.g., 2008 Wenchuan earthquake, approximately $8 \mathrm{~m}$, Yagi et al. 2012; 1999 Chi-Chi earthquake, approximately $8 \mathrm{~m}$, Shin and Teng 2001), past earthquakes in the Anko section of the MTL have probably been caused by a small number of relatively short displacements $(<10 \mathrm{~m})$ at moderate depths (e.g., $600 \mathrm{~m})$. However, there is as yet no geological evidence to explain how fault zones viewed today in outcrop have been uplifted from such depths to the surface. It can be speculated that uplift at approximately $4 \mathrm{~mm}$ year ${ }^{-1}$ during the Quaternary in and around the Akaishi Mountain Range (Chichibu Belt in Figure 1) caused by the Izu-Honshu collision (e.g., Dambara 1971) might have affected the Anko section of the MTL.

On the other hand, it is possible that high-temperature fluids might have triggered thermal pressurization during earthquakes in the Anko section of the MTL. An experimental evaluation by Wibberley and Shimamoto (2005) of hydraulic properties of fault-zone rocks from the Tsukide section of the MTL (Mie Prefecture) suggested that thermal pressurization likely occurred in the fault gouge there. This mechanism might also have affected the most recently active fault zone in the Anko section, but there are insufficient data on the hydraulic properties for the black gouge and surrounding rocks there to evaluate this possibility.

\section{Conclusions}

Our field and microscopic observations, mineralogical and geochemical analyses, modeling of fluid-rock interactions, and kinetic evaluation of geochemical data have shown that the black gouge within the most recently active fault in the Anko section of the MTL has been subjected to selective distortion of crystalline structure and granulation in clay minerals and high-temperature (up to $250^{\circ} \mathrm{C}$ ) fluidrock interactions associated with earthquake slip.

Our results demonstrate that the analytical approach and modeling we used are useful for investigations of earthquake slip, not only for sediment-hosted thrusts at subduction boundaries (Ishikawa et al. 2008; Hamada et al. 2011; Honda et al. 2011), but also for active inland granite-hosted faults. We have shown that in faults that define geological boundaries, entrainment of different types of rocks (granite versus basalt in this study) in slip zones must be taken into account during analysis and modeling. Our modeling also indicates that Arima-type fluids from depth might have been involved in earthquake slip on the MTL.

However, to more accurately evaluate the geochemistry of coseismic fluid-rock interactions on the MTL, experimental data are needed on the hydrothermal properties of black gouge from the MTL. The remarkably low abundances of total minerals and total clay minerals from XRD analyses of the black gouge probably indicate that insufficient time has elapsed since the most recent earthquake event to allow neocrystallization of clay minerals to occur. Further studies are needed on the kinetics of neocrystallization of minerals after distortion and amorphization by frictional forces.

\section{Competing interests}

The authors declare that they have no competing interests.

\section{Authors' contributions}

$\mathrm{TI}$ and $\mathrm{TH}$ designed this study and wrote the manuscript. NM prepared the samples and carried out geochemical and XRD analyses. KK carried out field observations. KF and JK supported interpretation of the data from microscopic observations and XRD analysis. YN carried out sampling and chemical analysis of the MTL mineral spring waters. YM and GH participated in the field study and chemical and XRD analyses. All authors read and approved the final manuscript.

\section{Acknowledgements}

We thank J. Matsuoka and K. Nagaishi for their work on chemical analyses. We also thank two anonymous reviewers and Editor C. Rowe for their constructive comments. This work was supported by Grants-in Aid for Science Research from MEXT and JSPS.

\section{Author details}

${ }^{1}$ Kochi Institute for Core Sample Research, Japan Agency for Marine-Earth Science and Technology (JAMSTEC), 200 Monobe-otsu, Nankoku Kochi 783-8502, Japan. ${ }^{2}$ Department of Earth and Space Science, Graduate School of Science, Osaka University, Toyonaka, Osaka 560-0043, Japan. ${ }^{3}$ Oshika Museum of Japan Median Tectonic Line, Oshika, Nagano 399-3502, Japan. ${ }^{4}$ Faculty of Education, Tokyo Gakugei University, Koganei, Tokyo 184-8501, Japan. ${ }^{5}$ Department of Earth and Planetary Science, Graduate School of Science, The University of Tokyo, Bunkyo-ku, Tokyo 113-0033, Japan. ${ }^{6}$ Department of Natural History Science, Graduate School of Science, Hokkaido University, Kita-ku, Sapporo 060-0810, Japan. ${ }^{7}$ Research and Development Center for Submarine Resources, JAMSTEC, Yokosuka, Kanagawa 237-0061, Japan.

Received: 13 November 2013 Accepted: 30 April 2014 Published: 20 May 2014 


\section{References}

Andrews DJ (2002) A fault constitutive relation accounting for thermal pressurization of pore fluid. J Geophys Res 107:2363, doi:10.1029/2002JB001942

Beck JW, Berndt ME, Seyfried WE Jr (1992) Application of isotopic doping techniques to evaluation of reaction kinetics and fluid/mineral distribution coefficients: an experimental study of calcite at elevated temperatures and pressures. Chem Geol 97:125-144

Biscaye PE (1965) Mineralogy and sedimentation of recent deep-sea clays in the Atlantic ocean and adjacent seas and oceans. Geol Soc Am Bull 76:803-832

Dambara T (1971) Synthetic vertical movements in Japan during the recent 70 years. J Geodetic Soc Jpn 17:100-108

Doan ML, Brodsky EE, Kano Y, Ma KF (2006) In situ measurement of the hydraulic diffusivity of the active Chelungpu Fault, Taiwan. Geophys Res Lett 33, L16317, doi:10.1029/2006GL026889

Eberl DD (2003) User's guide to RockJock-a program for determining quantitative mineralogy from powder X-ray diffraction data. USGS Open-File Rep 03:78

Fialko Y, Khazan Y (2005) Fusion by earthquake fault friction: stick or slip? J Geophys Res 110, B12407, doi:10.1029/2005JB003869

Hamada Y, Hirono T, Ishikawa T (2011) Coseismic frictional heating and fluid-rock interaction in a slip zone within a shallow accretionary prism and implications for earthquake slip behavior. J Geophys Res 116, B01302, doi:10.1029/2010JB007730

Hashizume T (1984) Geochemical study on occurrence of $\mathrm{NaCl}$ type spring on the outer part (Ina valley) of the central tectonic line. J Hot Spring Sci $35: 1-10$

Hirono T, Lin W, Yeh E-C, Soh W, Hashimoto Y, Sone H, Matsubayashi O, Aoike K, Ito H, Kinoshita M, Murayama M, Song S-R, Ma K-F, Hung J-H, Wang C-Y, Tsai Y-B (2006) High magnetic susceptibility of fault gouge within Taiwan Chelungpu Fault: nondestructive continuous measurements of physical and chemical properties in fault rocks recovered from hole B, TCDP. Geophys Res Lett 33, L15303, doi:10.1029/2006GL026133

Hirono T, Yokoyama T, Hamada Y, Tanikawa W, Mishima T, Ikehara M, Famin V, Tanimizu M, Lin W, Soh W, Song S (2007) A chemical kinetic approach to estimate dynamic shear stress during the 1999 Taiwan Chi-Chi earthquake. Geophys Res Lett 34, L19308, doi:10.1029/2007GL030743

Hirono T, Sakaguchi M, Otsuki K, Sone H, Fujimoto K, Mishima T, Lin W, Tanikawa W, Tanimizu M, Soh W, Yeh E-C, Song S-R (2008) Characterization of slip zone associated with the 1999 Taiwan Chi-Chi earthquake: X-ray CT image analyses and microstructural observations of the Taiwan Chelungpu Fault. Tectonophysics 449:63-84

Hirono T, Tanikawa W, Honda G, Kameda J, Fukuda J, Ishikawa T (2013) Importance of mechanochemical effects on fault slip behavior during earthquakes. Geophys Res Lett 40:2988-2992, doi:10.1002/grl.50609

Hirono T, Kameda J, Kanda H, Tanikawa W, Ishikawa T (2014) Mineral assemblage anomalies in the slip zone of the 1999 Taiwan Chi-Chi earthquake: ultrafine particles preserved only in the latest slip zone. Geophys Res Lett 41, doi:10.1002/2014GL059805

Hirose T, Mizoguchi K, Shimamoto T (2012) Wear processes in rocks at slow to high slip rates. J Struct Geol 38:102-116

Hoffman AW (2003) Sampling mantle heterogeneity through oceanic basalts: isotopes and trace elements. In: Holland HD, Turekian KK (eds) Treatise on geochemistry. Elsevier, Amsterdam, Vol. 2.03

Honda M, Nagai H, Nakasone T, Kuboki M, Sudoh M, Miyake T, Taniguchi H (1986) Distribution of rare earth elements in basaltic rocks. Proc Inst Nat Sci Nihon Univ 21:1-23

Honda G, Ishikawa T, Hirono T, Mukoyoshi H (2011) Geochemical signals for determining the slip-weakening mechanism of an ancient megasplay fault in the Shimanto accretionary complex. Geophys Res Lett 38, L06310, doi:10.1029/2011GL046722

Ichikawa K (1980) Geohistory of the Median Tectonic Line of southwest Japan. Mem Geol Surv Jpn 18:187-212

Ishihara S, Chappell BW (2007) Chemical compositions of the late Cretaceous Ryoke granitoids of the Chubu District, central Japan - revisited. Bull Geological Surv Jpn 58:323-350

Ishikawa T, Tanimizu M, Nagaishi K, Matsuoka J, Tadai O, Sakaguchi M, Hirono T, Mishima T, Tanikawa W, Lin W, Kikuta H, Soh W, Song S (2008) Coseismic fluid-rock interactions at high temperatures in the Chelungpu Fault. Nat Geosci 1:679-683
James RH, Allen DE, Seyfried WE Jr (2003) An experimental study of alteration of oceanic, crust and terrigenous sediments at moderate temperatures $\left(51^{\circ} \mathrm{C}\right.$ to $350^{\circ} \mathrm{C}$ ): insights as to chemical processes in near-shore ridge-flank hydrothermal systems. Geochim Cosmochim Acta 67:681-691

Jefferies SP, Holdsworth RE, Shimamoto T, Takagi H, Lloyd GE, Spiers CJ (2006) Origin and mechanical, significance of foliated cataclastic rocks in the cores of crustal-scale faults: examples from the Median Tectonic Line, Japan. J Geophys Res 111, B12303, doi:10.1029/2005JB004205

Kagami H, Tainosho Y, lizumi S, Hayama Y (1985) High initial Sr-isotopic ratios of gabbro and metadiabase in the Ryoke belt, southwest Japan. Geochem J 19:237-243

Kano Y, Mori J, Fujio R, Ito H, Yanagidani T, Nakao S, Ma K (2006) Heat signature on the Chelungpu Fault associated with the 1999 Chi-Chi Taiwan earthquake. Geophys Res Lett 33, L14306, doi:10.1029/2006GL026733

Kawamoto K, Ishikawa T, Matsuta N, Hirono T (2013a) Determination of the MTL geo-boundary fault and estimation of the protolith at the Anko Outcrop of the Median Tectonic Line, a Natural Monument of Nagano Prefecture, on the basis of petrography and bulk chemical analysis. Nat Hist Rep Inadani 14:1-17

Kawamoto T, Yoshikawa M, Kumagai Y, Mirabueno MHT, Okuno M, Kobayashi T (2013b) Mantle wedge infiltrated with saline fluids from dehydration and decarbonation of subducting slab. Proc Natl Acad Sci USA 110:9663-9668

Lachenbruch AH (1980) Frictional heating, fluid pressure and the resistance to fault motion. J Geophys Res 85:6097-6112

Lönnberg B, Lundström T (1994) Determination of grain size and lattice distortions in ground $\mathrm{YBa}_{2} \mathrm{Cu}_{3} \mathrm{O}_{7}$. J Mater Sci 29:2993-2997

Ma K, Lee C, Tsai Y, Shin T, Mori J (1999) The Chi-Chi Taiwan earthquake: large surface displacements on inland thrust fault. Eos 80:605-611

Ma K-F, Tanaka H, Song S-S, Wang C-Y, Hung J-H, Tsai Y-B, Mori J, Song Y-F, Yeh E-C, Soh W, Sone H, Kuo L-W, Wu H-Y (2006) Slip zone and energetics of a large earthquake from the Taiwan Chelungpu-fault Drilling Project. Nature 444:473-476

Matsushima N (1994) A new interpretation of median tectonic line of the Akaishi mountain lands, Japan. Bull lida City Mus 4:113-124

Mishima T, Hirono T, Soh W, Song SR (2006) Thermal history estimation of the Taiwan Chelungpu fault using rock-magnetic methods. Geophys Res Lett 33, L23311, doi:10.1029/2006GL028088

Morioka K, Tainosho Y, Kagami H (2000) Rb-Sr isochron ages of the cretaceous granitoids in the Ryoke belt, Kinki district, southwest Japan. Island Arc 9:46-54

Mukoyoshi H, Sakaguchi A, Otsuki K, Hirono T, Soh W (2006) Co-seismic frictional melting along an out-of-sequence thrust in the shimanto accretionary complex: implications on the tsunamigenic potential of splay faults in modern subduction zones. Earth Planet Sci Lett 245:330-343

Okano O, Sato T, Kagami H (2000) Rb-Sr and Sm-Nd isotopic studies of mafic igneous rocks from the Ryoke plutono-metamorphic belt in the Setouchi area, Southwest Japan: implications for the genesis and thermal history. Island Arc 9:21-36

Shin T, Teng T (2001) An overview of the 1999 Chi-Chi Taiwan earthquake. Bull Seism Soc Am 91:895-913

Sibson RH (1973) Interaction between temperature and pore-fluid pressure during earthquake faulting —a mechanism for partial or total stress relief. Nature Phys Sci 243:66-68

Sibson RH (1975) Generation of pseudotachylite by ancient seismic faulting. Geophys J R Astron Soc 43:775-794

Sun S-S, McDonough WF (1989) Chemical and isotopic systematics of oceanic basalts: implications for mantle composition and processes. In: Saunders AD, Norry MJ (eds) Magmatism in the ocean basins. Geological Society Special Publication No. 42, London, pp pp313-345

Tanaka H, Takagi H, Inoue M (1996) Mode of cataclastic deformation and hydrothermal alteration of the fault rocks and history of fault activity along the median tectonic line, central Japan. J Tectonic Res Group Jpn 41:3-44

Tanikawa W, Sakaguchi M, Hirono T, Lin W, Soh W, Song S (2009) Transport properties and dynamic processes in a fault zone from samples recovered from TCDP hole B of the Taiwan Chelungpu Fault Drilling Project. Geochem Geophys Geosyst 10, Q04013, doi:10.1029/2008GC002269

Vdovic N, Jurina I, Skapin SD, Sondi I (2010) The surface properties of clay minerals modified by intensive dry milling. Appl Clay Sci 48:575-580

Wibberley CA, Shimamoto T (2005) Earthquake slip weakening and asperities explained by thermal pressurization. Nature 436:689-692 
Wu H, Ma K, Zoback M, Boness N, Ito H, Hung J, Hickman S (2007) Stress orientations of Taiwan Chelungpu-fault Drilling Project (TCDP) hole-A as observed from geophysical logs. Geophys Res Lett 34, L01303, doi:10.1029/2006GL028050

Yagi Y, Naoki N, Kasahara A (2012) Source process of the 12 May 2008

Wenchuan, China, earthquake determined by waveform inversion of teleseismic body waves with a data covariance matrix. Earth Planets Space 64:e13-e16, doi:10.5047/eps.2012.05.006

You C-F, Castillo PR, Gieskes JM, Chan LH, Spivack AJ (1996) Trace element behavio in hydrothermal experiments: implication for fluid processes at shallow depths in subduction zones. Earth Planet Sci Lett 140:41-52

Yund RA, Blanpied ML, Tullis TE, Weeks JD (1990) Amorphous material in high strain experimental fault gouges. J Geophys Res 95:15589-15615

doi:10.1186/1880-5981-66-36

Cite this article as: Ishikawa et al:: Geochemical and mineralogical characteristics of fault gouge in the Median Tectonic Line, Japan: evidence for earthquake slip. Earth, Planets and Space 2014 66:36.

\section{Submit your manuscript to a SpringerOpen ${ }^{\circ}$} journal and benefit from:

- Convenient online submission

- Rigorous peer review

- Immediate publication on acceptance

- Open access: articles freely available online

- High visibility within the field

- Retaining the copyright to your article 